\title{
El nacionalismo ruso y sus visiones geopolíticas de Eurasia
}

\author{
Carles JOVANÍ GIL \\ Departamento de Geografía \\ Facultad de Geografía e Historia \\ Universitat de València \\ c.jovani@uv.es
}

Recibido: 16-09-2014

Aceptado: 21-12-2014

\begin{abstract}
RESUMEN
En este artículo se escrutarán los fundamentos, evolución y atributos de las principales corrientes contemporáneas de pensamiento geopolítico ruso, haciéndose especial énfasis en la posición que ocupa Eurasia en sus respectivos imaginarios. Como se observará, el nacionalismo se ha consagrado como leitmotiv en el discurso político ruso durante el último siglo y medio, adquiriendo una preeminencia renovada con su versión eurasianista. Con el renacimiento de sus ideas se constata también la vuelta de la geografía y de la tesis del Heartland de Mackinder a la primera línea de la política.
\end{abstract}

Palabras clave: Rusia; Eurasia; nacionalismo; eurasianismo; Heartland.

\section{Russian Nationalism and Its Geopolitical Visions of Eurasia}

\begin{abstract}
This work examines the fundamentals, evolution and attributes of the main currents of contemporary Russian geopolitical thought. Special emphasis will be placed on the position awarded to Eurasia in their respective imaginaries. The article makes the point that over the last century and a half, nationalism has been enshrined as a leitmotiv in Russian political discourse wherein a renewed Eurasianist version has gained unprecedented preeminence. With the renaissance of its ideas, it gets proven that the return of geography and Mackinder's Heartland thesis are back to the forefront of politics.
\end{abstract}

Key words: Russia; Eurasia; Eurasianism; nationalism; Heartland.

\section{O nacionalismo russo e suas visões geopolíticas da Eurásia}

\section{RESUMO}

Neste artigo serão explorados os fundamentos, a evolução e os atributos das principais correntes contemporâneas do pensamento geopolítico russo, enfatizando a posição ocupada pela Eurásia em seus respectivos imaginários. Como poderá ser observado, o nacionalismo consagrou-se como leitmotiv no discurso político russo durante o último século e meio, adquirindo uma preeminência renovada com sua versão "eurasianista". Com o renascimento de suas ideias, constata-se também a volta da geografia e da tese do Heartland de Mackinder à primeira linha da política.

Palavras-chave: Rússia; Eurásia; nacionalismo; eurasianismo; Heartland. 


\section{REFERENCIA NORMALIZADA}

Jovaní Gil, Carles (2014) "El nacionalismo ruso y sus visiones geopolíticas de Eurasia”. Geopolítica(s). Revista de estudios sobre espacio y poder, vol. 5, núm. 2, 165-206.

SUMARIO: Introducción. 1. La dimensión geográfica del nacionalismo. 2. Los orígenes del pensamiento geopolítico ruso. 2.1. El occidentalismo como vector de modernización y transformación social. 2.2. El eslavofilismo y el eterno retorno a las esencias. 2.3. El paneslavismo y la hermandad de los pueblos eslavos. 3. La dialéctica entre el nacionalismo ruso y las minorías étnicas durante el período soviético. 3.1. Internacionalismo contra revolución nacional en el bolchevismo temprano. 3.1. Internacionalismo contra revolución nacional en el bolchevismo temprano. 3.3. La renacionalización rusa bajo el yugo estalinista. 3.4. El espejismo pluralista de la era Jruschov. 3.5. El proyecto brezhneviano del "homo sovieticus". 3.6. El giro aperturista de Gorbachov y el resurgir de las naciones. 4. El nacionalismo ruso en el pensamiento geopolítico de Posguerra Fría. 4.1. El neoeurasianismo o el renacer de las aspiraciones imperiales de Rusia. 5. La teoría del Heartland de Mackinder como piedra angular del pensamiento eurasianista. 5.1. La crisis de Ucrania de 2013 y 2014. La pugna por el control de una pieza clave en el tablero geopolítico euroasiático. Consideraciones finales: la restitución de la centralidad del nacionalismo ruso de corte eurasianista. Bibliografía.

\section{Introducción}

La cultura imperial rusa es producto de una ambigüedad psicológica que se remonta a los tiempos premodernos de los zares. El pueblo ruso nunca desarrolló una identidad que pudiera contenerse dentro de los límites modernos del Estado-nación (Lake y Morgan, 1997: 228), lo que justificaría que el discurso nacionalista, ubicuo en la Rusia postsoviética, esté plagado de referencias irredentistas que sitúan a Eurasia como espacio privativo de influencia. Tal y como señalara en su día Max Weber (1920: 252), "las «imágenes del mundo» [...] han servido frecuentemente como interruptores para determinar [...] el movimiento de las acciones”. En el escenario de Posguerra Fría son múltiples las escuelas de pensamiento que se baten por ganar capacidad de influencia sobre la nomenklatura moscovita. Cada una de ellas responde a una cosmovisión con una serie de valores y representaciones espaciales de la nación particulares. La trascendencia de este debate no es baladí, puesto que de su desenlace depende el diseño de un programa de política exterior en el que el antiguo espacio soviético ocupa un lugar preponderante ${ }^{1}$.

Partiendo de esta premisa, a lo largo de las páginas siguientes se escrutarán los fundamentos, evolución y atributos de las principales corrientes contemporáneas de pensamiento geopolítico ruso, haciéndose especial énfasis en la posición que ocupa

${ }^{1}$ El Concepto Nacional de Seguridad de la Federación Rusa establece que "los intereses nacionales rusos en la esfera internacional yacen en [...] el desarrollo de relaciones en pie de igualdad y mutuamente ventajosas [...] principalmente con miembros de la Comunidad de Estados Independientes [...]" (Ministry of Foreign Affairs of the Russian Federation, 2000). 
en sus respectivos imaginarios la región euroasiática. Con ello se pretende identificar la influencia -explícita o implícita - de la teoría del Heartland en las principales corrientes de pensamiento geopolítico ruso, y en particular en la gestión llevada a cabo por Moscú en la actual crisis ucraniana. Como se observará, el nacionalismo se ha consagrado como leitmotiv en el discurso político ruso durante el último siglo y medio, adquiriendo una preeminencia renovada desde finales de los años ochenta su versión eurasianista. Tal doctrina mantiene paralelismos estructurales con la teoría que a principios del siglo XX formulara el geógrafo británico Halford Mackinder, y al igual que esta última presenta como objetiva una realidad que de acuerdo a los preceptos de la geopolítica crítica resultaría estar abierta a infinitas reformulaciones en función del contexto ideológico, político, económico e histórico en el que se inscribe quien la dibuja (Ó Tuathail, 1996).

\section{La dimensión geográfica del nacionalismo}

Toda corriente política que busque expresar, articular y promover los intereses de una nación puede definirse como nacionalista. Gellner (1983: 129-130) asevera que el nacionalismo no puede ser rechazado como un accidente desafortunado de la historia, puesto que todavía es una motivación básica dentro de la organización política del mundo moderno. Más allá de cualquier caracterización minimalista, la academia ha permanecido dividida respecto a las causas subyacentes a la aparición del movimiento nacionalista y al grado desigual de penetración de sus ideas. Las dos aproximaciones principales desde las que se aborda su estudio son la primordialista y la modernista. La premisa básica de la primera es que los lazos grupales se basan en la sangre, la raza, la religión o la costumbre, y son más fuertes que cualquier otro -incluida la ideología o la clase social-, especialmente en sociedades con un escaso grado de desarrollo de las instituciones democráticas. En el caso que nos ocupa asumen que el sentimiento nacional ruso siempre ha sido fuerte, si bien fue aplacado durante décadas por la ideología comunista. Por su parte, las teorías modernistas apuntan al carácter fluido y cambiante de la identidad nacional, y argumentan que el nacionalismo es el resultado de la manipulación de la identidad como medio para ganar o retener el poder. La escuela institucionalista aduce, en particular, que el surgimiento del nacionalismo en el antiguo espacio soviético es resultado de la política comunista de institucionalización de la etnicidad (Brudny, 2000: 1-3).

Smith (1983: 171) define en primera instancia el nacionalismo como "un movimiento ideológico para la consecución y mantenimiento del autogobierno e independencia en nombre de un grupo, algunos de cuyos miembros lo conciben como una nación potencial o real”. Carter (1990: 3) critica este paradigma al considerar que mantendría únicamente vigencia en el caso de nuevos Estados-nación, careciendo por consiguiente de aplicabilidad para el estudio de Rusia. El propio Smith 
(1991: 14) definirá posteriormente la “nación” como “una población humana dada que comparte un territorio histórico, mitos comunes y memoria histórica, una cultura pública y de masas, una economía común, y derechos legales comunes y deberes para todos sus miembros". Su propuesta etnosimbólica, compartida en este trabajo, pretende superar el dualismo interpretativo entre primordialismo e instrumentalismo a fin de permitir una lectura integrada de elementos antes polarizados en el debate académico. Esta aproximación presenta el nacionalismo como un fenómeno moderno, pero incorpora también a la nación rasgos fundamentales de las comunidades étnicas premodernas que hacen que las elites que persiguen la creación de Estados-nación no tengan completa autonomía respecto al contexto cultural e ideológico en el cual operan (Savarino, 2007: 42-43).

Brudny (2000: 5) distingue tres componentes básicos en la arquitectura de cualquier expresión nacionalista: la definición de los miembros de la nación, que vendría determinada bien por la adscripción cívico-territorial o por caracteres étnicos; el acervo político, social, económico y cultural de la misma, que condiciona la orientación y aspiraciones políticas de la clase dominante; y su extensión geográfica, acotada por la distribución espacial del grupo étnico en su variante más privativa, o también por integrantes de otras nacionalidades en su categoría imperial. La geografía se postula, pues, como una parte esencial de la identidad nacional, y el nacionalismo se presenta como una doctrina intrínsecamente geográfica que busca dotar a una colectividad humana autodefinida de un sustrato espacial definido y soberano (Kaplan y Herb, 1999: 2-3). Las estrategias de los movimientos nacionalistas "son en esencia [...] territoriales, en el sentido de que, a diferencia de otros fenómenos sociales, [...] se sirven ideológicamente - y explícitamente- del territorio" (Nogué, 1998: 24). En el imaginario grupal el espacio hace la doble función de evocación de elementos representativos de la comunidad y de delineación de los confines dentro de los cuales moran individuos que comparten el sentimiento de pertenencia a una misma nación.

Smith (1991: 16) subraya que las naciones "demarcan un territorio histórico que sitúa a la comunidad en el tiempo y en el espacio” y que permite a su vez la identificación por oposición al "otro". Los movimientos nacionalistas se han procurado a lo largo de los tiempos la conformación de una imagen prospectiva ideal, y a tal fin no han dudado en convertir elementos del paisaje en iconos nacionales además de proceder a la tarea de delimitar los confines precisos de la comunidad (Kaplan y Herb, 2011: 349). En el caso de Rusia, el trazado de sus fronteras ha variado enormemente con el devenir del tiempo, configurando una realidad nacional compleja y en continua redefinición. Los límites geográficos que jalonan el territorio en cuyo interior emana y se propaga la esencia del acervo ruso han sido ampliamente discutidos en el último siglo y medio. Todavía hoy el debate permanece abierto y es fuente de discrepancia entre las élites que dirigen el sistema político ruso. Al contrario de lo que pudiera parecer, no se trata ésta de una cuestión trivial circunscrita a la esfera del debate de las clases populares, ni tampoco de una vieja controversia 
que ha saltado del reducto de la alta academia a la esfera política. Consiste, antes bien, en el intento de dar respuesta a una ecuación irresuelta que encierra la respuesta a la raison d'être rusa.

\section{Los orígenes del pensamiento geopolítico ruso}

El pensamiento geopolítico ruso estuvo determinado durante siglos por una supuesta "idea rusa" (russkaya ideia) de la que se derivaría una misión imperial y civilizadora ineludible. Pedro el Grande (1689-1725), inspirado por el absolutismo ilustrado, el constitucionalismo y el radicalismo europeos, introdujo profundos cambios de corte renovador y aperturista en la vida política, económica y social del país, que romperían con la tradición imperante hasta la fecha. Serguéi Uvárov, Ministro de Educación de la administración zarista de Nicolás I, formuló en 1832 la teoría de la nacionalidad oficial, que conjugaba los conceptos de ortodoxia, autocracia y "nacionalidad" (narodnost) ${ }^{3}$. Aceptada por el emperador, la nueva doctrina sobrevivió hasta el final de la monarquía en 1917, y supuso en la práctica el inicio de un período de oscurantismo y aislacionismo cultural. Las reacciones ante esta posición no tardaron en llegar, y Pyotr Chaadayev, académico de origen noble, acabaría abriendo en sus Cartas filosóficas ${ }^{4}$ un debate intelectual que constituyó la génesis de dos posiciones políticas que se enfrentarían a lo largo del siglo XIX: el occidentalismo y el eslavofilismo (Utechin, 1964: 71-77).

\subsection{El occidentalismo como vector de modernización y transformación social}

El occidentalismo fue la corriente dominante en el pensamiento político ruso durante el siglo XIX y principios del XX (Utechin, 1964: 91). A diferencia del eslavofilismo, que exploraba el pasado en busca de las raíces de la singularidad rusa y atribuía los males que laceraban la sociedad decimonónica eslava a la influencia del liberalismo europeo, el occidentalismo deploraba el retraso de su país, denunciaba

\footnotetext{
2 Aunque el concepto de "idea rusa” fue acuñado por Vladímir Soloviyev en 1888, la tradición de reflexión intelectual sobre la identidad rusa existía previamente y convergía en una serie de valores transversales y autorreferenciales que configuraban un proyecto nacional o misión histórica. Para uno de los primeros y más detallados estudios sobre este concepto, véase Berdiáyev (1947).

${ }^{3}$ El concepto de "ortodoxia” implicaba devoción por las enseñanzas de la Iglesia Ortodoxa Rusa y constituía una reacción al escepticismo de la Ilustración. La afirmación del principio de "autocracia” significaba el final de las políticas liberales con las que Catalina II y Alejandro I habían experimentado. En último término, la "nacionalidad" se interpretaba como el amor por la herencia nacional y la idiosincrasia rusa.

${ }^{4}$ En su magnus opera culpaba al acervo de la cristiandad oriental de la ignorancia, el barbarismo y la crueldad en el que había vivido sumido el pueblo ruso durante siglos.
} 
la inadecuación y lentitud de las reformas y protestaba por el anquilosamiento de unas instituciones obsoletas (Anderson, 1967: 196). Sus impulsores querían que Rusia continuara por el camino de las reformas iniciado por Pedro el Grande y se acercase así al modelo político y social de la Europa occidental (Jahn, 2004: 62). Desde sus orígenes en los escritos dieciochistas de Radischev y la posterior reformulación de Herzen y Chernyshevsky (Tolz, 2010: 205), esta corriente se ramificó progresivamente en diferentes tendencias que respondían grosso modo a las que análogamente iban desarrollándose en Europa occidental ${ }^{5}$. Sin embargo, los occidentalistas tempranos nunca rindieron culto a Occidente de manera incondicional, sino que buscaban reformar a Rusia mediante el recurso a algunas de las mejores atribuciones de la Vieja Europa, a saber las libertades civiles y políticas, aunque conservando aquellas partes que admiraban de la herencia eslava. La libertad personal representaba uno de los elementos más anhelados habida cuenta del férreo control a que era sometido el pueblo por parte de la administración zarista. Las coincidencias entre las principales sensibilidades occidentalistas respecto al diagnóstico de las necesidades se tornaban, no obstante, discrepancias, a la hora de dirimir los medios para avanzar hacia una sociedad más libre y justa (Utechin, 1964: 91-127). Mientras que los liberales consideraban el establecimiento de instituciones parlamentarias y la introducción del capitalismo como requisitos sine qua non para garantizar la libertad individual, los socialistas recelaban del libre mercado y daban prioridad a los problemas económicos y sociales (Anderson, 1967: 194-212). Al fin y al cabo, según ellos, el sistema legal bajo Nicolás I no difería en gran medida del código napoleónico ${ }^{6}$. Esta línea argumentativa dominaría el pensamiento socialista ruso desde el populismo clásico de 1860 hasta el encumbramiento de Lenin en la segunda década del siglo XX (Tolz, 2010: 16).

\subsection{El eslavofilismo y el eterno retorno a las esencias}

El eslavofilismo hunde sus raíces en el romanticismo alemán y el idealismo, y apareció como una reacción filosófica contra el "devastador" racionalismo de Hume, Voltaire y la Revolución Francesa (Anderson, 1967: 213). Sin embargo, no quedó restringido a la esfera de las ideas políticas, sino que abrazó la teología, la filosofía, la historiografía, la crítica literaria e incluso las ciencias naturales. Aunque nunca fue un movimiento compacto con un programa definido, los eslavófilos tenían ciertos puntos en común: compartían la idealización de la Rusia prepetrina; insistían

\footnotetext{
${ }^{5}$ Utechin (1964: 91-127) distingue entre conservadurismo, liberalismo, radicalismo no socialista y socialismo temprano.

${ }^{6}$ Promulgada el 21 de marzo de 1804, la denominada “Constitución Civil de los Franceses” es la base del actual derecho civil francés.
} 
en la misión histórica del pueblo ruso; y creían en la unidad subyacente de las naciones eslavas basada en la ortodoxia cristiana como principal elemento cohesionador.

Para esta corriente, la religión constituía el elemento central del to -incluido el pensamiento político-, puesto que no sólo era importante para la salvación del individuo, sino también para promover la unión y el consenso moral que daba consistencia a la nación (Anderson, 1967: 214). El líder de esta escuela, Jomiakov, argumentaba que el desarrollo histórico ruso, determinado por el espíritu comunal del pueblo y la Iglesia Ortodoxa, difería del de la Europa occidental. De acuerdo con sus postulados, la Iglesia de Oriente no aspiraba a poder temporal, por lo que no existía rivalidad entre la misma y el Estado, a diferencia de lo que pasaba en el flanco occidental del Viejo Continente. Allí jamás se había podido evitar la elección entre las alternativas de dominación de la Iglesia y negación del Estado, como era el caso de los católicos romanos, o de dominación del Estado y negación de la Iglesia, como hacían los protestantes. La relación normal entre ambas instituciones debería ser armoniosa y basada en reconocimiento mutuo, y así habría resultado durante siglos antes que la influencia del catolicismo romano confiriera al Patriarcado de Moscú un cariz papista y desafiante ante el Estado. El mandato de Pedro el Grande habría supuesto, pues, la destrucción de la antigua comunión entre los dos entes mediante la subordinación de la Iglesia al Estado y la introducción por la fuerza de prácticas occidentalizadoras que alienarían a las altas esferas de la sociedad rusa del momento (Utechin, 1964: 78-90). Para Kireyevsky, tales prácticas, construidas a partir de principios racionalistas ${ }^{7}$, habrían provocado una dramática deformación del mensaje original del cristianismo en favor de un individualismo que haría de la sociedad un conglomerado de personas autócratas en lugar de un todo orgánico (Zapater, 2005: 24).

Pese al incipiente paralelismo cultural entre la Rusia pospetrina y Europa, las diferencias en el campo de lo político continuaban siendo notables. Europa occidental era percibida como la cuna del constitucionalismo, de la democracia y del institucionalismo parlamentario, elementos todos reprobados por los eslavófilos. El individuo era en Occidente una simple categoría judicial que contrastaba con la posición preeminente que ocupaba en el seno de la sociedad rusa. Asimismo, las instituciones democráticas eran vistas como una máscara que ocultaba desigualdades y explotación, crítica que alcanzaría su máximo apogeo con la aparición del populismo $^{8}$ en la década de 1860 (Tolz, 2010: 204-205). En cuanto al discurso

\footnotetext{
${ }^{7}$ De acuerdo al etnógrafo, filólogo y folklorista ruso, estarían enraizadas en la herencia pagana del Imperio romano, que representaría la "dominación de los intereses materiales". Véase Tolz, (2010: 202).

${ }^{8}$ El populismo es utilizado por los historiadores del pensamiento ruso en tres sentidos diferentes: el más amplio incluye cualquier político e intelectual que apoyara al socialismo revolucionario; también se refiere a los reformistas socialistas de finales del siglo XIX; y, finalmente, alude a aquellos escritores y políticos que
} 
nacionalista imperante, la historia europea y sus conquistas imperiales eran presentadas como violentas, en contraste con un pasado idílico propio que cristalizaría en la creación de un Imperio ruso orgánico y natural. De este modo, el papel de Rusia en su glacis geopolítico era considerado por muchos intelectuales eslavófilos como más humano -y, por ende, más legítimo- que la sangrienta colonización y esclavismo británicos (Tolz, 2010: 208).

Los fundamentos axiológicos del movimiento eslavófilo se basaban, pues, en el rechazo sistemático a los usos y modas de Occidente, llegando a adquirir incluso tintes de hostilidad hacia ellos ${ }^{9}$. Las sociedades europeas serían así duramente criticadas por la corrupción de su moral, el excesivo materialismo, la fijación en los intereses personales, la hipocresía de su sistema político y la banalidad de la cultura burguesa (Tolz, 2010: 203). Sus simpatizantes destilaban generalmente una actitud conservadora que atribuía cualquier deficiencia de la sociedad a las reformas mal concebidas que no habían evolucionado orgánicamente del espíritu del pueblo (Anderson, 1967: 213-230). La fórmula política que preconizaban se basaba en la plenitud de poder para el zar ${ }^{10}$, la libertad de expresión y de prensa, y la desaparición de la servidumbre, patrón que se había mantenido operativo en Rusia desde tiempos del gran Estado ruso de Kiev hasta la introducción del absolutismo ilustrado de Pedro el Grande. En relación a esta última cuestión, Samarin ${ }^{11}$ llegó a defender la necesidad no sólo de liberar a los siervos físicamente, sino también de transferirles - bien directamente o de manera comunal- el título de parte de las tierras pertenecientes a sus amos para evitar la proletarización (Utechin, 1964: 78-90).

En suma, el pensamiento eslavófilo, más reaccionario que conservador, hacía un llamamiento tácito a lo nacionalista, lo introspectivo, lo defensivo y lo religioso que atraería a muchos de los intelectuales rusos más prominentes de la época (Anderson, 1967: 230). Frente a la defensa occidental de la Libertad concebida como suma de racionalismo, individualismo y cosmopolitismo, oponía tal idea como agregado de conocimiento espiritual, colectivismo y nacionalismo (Zapater, 2005: 27). Dos de sus ideas centrales perdurarían en el tiempo e inspirarían futuras líneas de pensa-

se asumían la representación de los intereses genuinos y las visiones del pueblo, esto es, del campesinado. Véase Utechin, (1964: 128).

${ }^{9}$ Sin embargo, no todo en la cultura occidental merecía ser criticado. El progreso científico y, especialmente, la manera en que los europeos habían sido capaces de preservar su "idiosincrasia nacional” (samobytnost) eran frecuentemente objeto de alabanza. Los rusos, por su parte, habrían renegado de su pasado para convertirse en europeos.

${ }^{10}$ A pesar de esta afirmación, los eslavófilos pensaban que los burócratas del Kremlin distaban mucho de ser infalibles, y exigían mayor receptividad a sus querencias.

${ }^{11}$ Filósofo y escritor ruso de origen noble considerado uno de los principales arquitectos de la Reforma Emancipadora de 1861, que significó el fin de la servidumbre a que estaba sometida gran parte del campesinado ruso. 
miento: la idea de espíritu comunal del pueblo ruso, y la idea que los rusos compartían características comunes con otros eslavos (Utechin, 1964: 84).

\subsection{El paneslavismo y la hermandad de los pueblos eslavos}

El paneslavismo moderno o eslavofilismo de segunda generación apareció entre los eslavos occidentales y meridionales a mediados del siglo XIX, y posteriormente fue ganando adhesiones en Rusia ${ }^{12}$, especialmente entre miembros de una de las organizaciones decembristas ${ }^{13}$, la Sociedad de los Eslavos Unidos ${ }^{14}$. Los decembristas pretendían la "liberación" de todos los eslavos y la formación de una federación democrática en la que Rusia sería un miembro más. Tras el fracaso de la revolución, Pogodin, uno de los adalides de la teoría de la nacionalidad oficial, ocupó la presidencia de la principal organización paneslávica del momento, la Sociedad Benevolente Eslávica de Moscú. Tal organización, de talante moderado y una gran heterogeneidad, perseguía únicamente la promoción de la solidaridad política y cultural entre los eslavos. Poco tenía que ver con la ideología extremista que difundió Danilevski en su obra Rusia y Europa, en la que avanzaba una de las primeras teorías de tipos culturales o civilizaciones que mantenía analogías con las clasificaciones taxonómicas de especies que se realizaban en la época. De acuerdo con sus principios, Rusia no sería parte de Europa y conformaría con el resto de eslavos un tipo cultural diferenciado y superior al occidental que debería constituir la simiente de una nueva civilización. Así las cosas, los eslavos deberían liberarse de la tutela germana y turca para unirse a Rusia y formar un gran imperio encabezado por la figura del zar (Utechin, 1964: 84-87). Este imperio tendría como finalidad última cumplir la misión histórica de Rusia, que pasaría por el retorno de Constantinopla a la Ortodoxia. A tal efecto, sería indispensable su rearme para erigirse como superpotencia e infundir respeto a posibles contendientes.

\footnotetext{
${ }^{12}$ La apertura de un período de incertidumbre tras la muerte de Nicolás I en 1855 había polarizado la sociedad entre liberales y conservadores, forzando a la segunda generación de eslavófilos a formar una alianza con los tradicionalistas y catalizando en último término su movimiento hacia una postura fervorosamente antiliberal. La llegada al trono del contrarreformista Alejandro III conllevaría la comunión final entre paneslavistas y zaristas, gestándose una ideología mesiánica, extremadamente nacionalista, antioccidental, antisemita y expansionista. Véase Zapater (2005: 26-28).

${ }^{13}$ La revuelta decembrista fue un intento de golpe de Estado militar que tuvo lugar el 14 de diciembre de 1825 en San Petersburgo. Esta acción pretendía forzar al futuro emperador Nicolás I a aprobar una constitución de corte liberal.

${ }^{14}$ Algunos autores fechan el nacimiento del paneslavismo en invierno de 1857-1858, período en que se creó la Sociedad Benevolente Eslávica de Moscú para ayudar a los eslavos meridionales a combatir la amenaza otomana. Véase Millar (2004: 1133).
} 
El trabajo teórico más importante de los inspiradores de esta corriente fue la profundización del significado y el entendimiento de la nacionalidad rusa y su relación con la ortodoxia. La idealización de la unidad de la Iglesia del Este llevó a Leontiev a concebir un imperialismo autoritario construido a imagen del Imperio Bizantino. Por su parte, Fiódor Dostoyevski ${ }^{15}$, pese a su limitada aportación al desarrollo de las bases ideológicas de esta escuela, contribuyó como ningún otro a la divulgación de sus postulados aprovechando la alta notoriedad que había alcanzado como novelista. Una vez más, consideraba que la Iglesia Ortodoxa, como fuerza cohesiva, era la expresión de la unidad de la nación, que no se circunscribía a los límites del Imperio ruso. No obstante, dudaba de que el resto de eslavos reconocieran el papel central de Rusia en un hipotético proyecto futuro compartido, por lo que rechazaba el expansionismo de Moscú al considerarlo contraproducente (Anderson, 1967: 226-228). Aunque el paneslavismo no llegó a convertirse en este periodo en componente medular de la política exterior rusa, contribuyó sin embargo al cambio de la acepción étnicamente neutral de nacionalidad que había usado la monarquía por otra que incorporaba un ferviente nacionalismo ruso con ecos imperiales.

\subsection{El eurasianismo y el sueño imposible del imperio supranacional}

La firma del Tratado de Berlín ${ }^{16}$ en 1878 fue ampliamente percibida como una humillación entre la intelligentsia rusa, llevando a algunos de sus integrantes a distanciarse del paneslavismo y desviar paulatinamente su mirada hacia el este. De esta manera, los desde entonces conocidos como "orientalistas" (vostochniky) pasarían a considerar por primera vez el carácter imperial del país como componente medular de su idiosincrasia. Ello quedaría patente al suscribir la teoría del "mundo medio” desarrollada por el lingüista Vladimir I. Lamanski ${ }^{17}$, que concedía al emplazamiento geográfico y a la diversidad étnica del imperio un papel principal en la definición de la identidad nacional. Uno de sus contemporáneos, Konstatin Leontiev, fue incluso más lejos al abrir Rusia hacia el mundo asiático y anticipar

\footnotetext{
${ }^{15}$ Es considerado uno de los escritores más importantes de la Rusia zarista y se encuentra entre los más prominentes de la literatura universal. En su obra explora la psicología humana en el contexto sociopolítico decimonónico ruso.

${ }^{16}$ Este tratado fue el acto final del Congreso de Berlín, una asamblea diplomática donde representantes de diversas potencies europeas reorganizaron los Balcanes tras el fin de la Guerra ruso-turca (1877-1878). Estipulaba, entre otras regulaciones, la autonomía de Bulgaria, que había sido reducida en relación a sus fronteras históricas. Este hecho acabó con los intentos rusos de crear una "Gran Bulgaria” aliada.

${ }^{17}$ En su libro Los tres mundos del continente euroasiático, publicado en 1892, introducía la idea de Rusia como "tercer continente" y rechazaba la división clásica entre Europa y Asia a lo largo de los Urales. Véase Sengupta (2009: 28-30).
} 
que únicamente podría prescindir de Europa si aprendía a verse como "turania”"18 en lugar de eslava. Con el transcurso del tiempo un importante número de intelectuales nacionalistas dejó de definir la nación en términos de filiación lingüística para empezar a hacerlo en base a sus características fisiográficas. No obstante, según matiza Laruelle (2008a: 2-4), lejos de representar este hecho el triunfo de una nueva concepción política, constituía en los estertores del siglo XIX la mayor parte de las veces un mero paliativo geoestratégico ante el manifiesto fracaso de las aspiraciones expansionistas de Moscú en su flanco occidental.

El eurasianismo como concepto y movimiento fue concebido por Petr Savistki durante su exilio en las postrimerías de la Guerra Civil Rusa en la península de Crimea, uno de los últimos bastiones del Ejército Blanco. Posteriormente, esta idea tomaría forma entre los círculos de emigrados antibolcheviques en Bulgaria y vería finalmente la luz con el manifiesto Éxodo hacia el Este, publicado en 1921 (Shlapentokh, 1997: 130). Se trata éste de un movimiento profundamente heterogéneo e ideológicamente fragmentado cuyos principios se adaptaron con éxito a diferentes coyunturas, razón que explicaría en último término su perdurabilidad y amplia cobertura en la Rusia de hoy. A pesar de su carácter camaleónico, es posible reconocer una serie de axiomas comunes a todas sus manifestaciones: el rechazo a Europa, a Occidente y al capitalismo; la afirmación de la unidad cultural y el destino histórico común de los rusos y otros pueblos del antiguo Imperio así como de sus inmediaciones; la idea que de la centralidad geográfica del espacio euroasiático se deriva una forma imperial de organización política; el culto retórico a la diversidad nacional combinado con un rechazo a la autonomía real de las minorías; y la creencia en la existencia de constantes culturales que explican el significado profundo de los acontecimientos políticos contemporáneos (Laruelle, 2008a).

Los eurasianistas clásicos adoptaron los principales postulados de la "idea rusa", aunque añadiendo un elemento determinista geográfico derivado de su posición de centralidad en el continente. Remarcaban así las diferencias respecto a Europa, oponiendo la espiritualidad, la tolerancia y el colectivismo social propios al individualismo, el materialismo y la violencia colonial occidental. Además, creían en la capacidad del pueblo ruso para crear una sociedad euroasiática "orgánica” contenida en un universo geográfico cerrado que debía brindarles todos los recursos materiales y espirituales necesarios para la autosubsistencia, lo que daría lugar a la aparición del concepto "mundo en sí" (mir v sebe). Este credo de porte estatista y aislacionista mantendría paralelismos con la autarquía promovida por la nomenklatura durante los primeros compases del régimen soviético. En lo que respecta a sus

\footnotetext{
${ }^{18}$ El término "turanio" se refiere en este contexto al conjunto de los pueblos que hablarían lenguas pertenecientes a una supuesta familia uralo-altaica. Una propuesta que a pesar del amplio apoyo de que gozó en el siglo XIX fue desechada por la lingüística en los años 1960.
} 
relaciones con el poder, aunque en un principio fueron críticos con el nuevo régimen al considerar inaceptable el excesivo control estatal sobre todos los dominios de las esferas pública y privada, acabaron bendiciendo su derivada totalitaria y aproximándose a la cada vez más nacionalista elite soviética (Shlapentokh, 1997). De ésta valoraban la capacidad para articular un partido disciplinado que había sido capaz de gestar un complejo multiétnico, pero ello no les privaba de criticar su ateísmo y su obstinada oposición a la propiedad privada, lo que acabaría valiéndoles el calificativo de "bolcheviques ortodoxos" o "revolucionarios conservadores" (Bassin, 2008: 294-297; Levchuk, 2013: 29-31).

Una de las figuras más prominentes de esta escuela, Nikolái Trubetskói, equipararía - como hiciera Savitski- Rusia a Eurasia en una fórmula programática que englobaba a los dos continentes en una única entidad geopolítica (Astrov y Morozova, 2008: 10). El lingüista moscovita afirmaba que la configuración geográfica del continente euroasiático había condicionado la formación y el desarrollo de una civilización que absorbía y entremezclaba elementos europeos y asiáticos en una combinación que no tenía parangón. A partir de ello infería que Rusia era euroasiática en lugar de eslava no sólo desde el punto de vista cultural sino también racial y antropológico. Dado el carácter multiétnico de este espacio resultaba pertinente abandonar el nacionalismo particularista ruso, que se arrogaba una posición hegemónica en el continente, para abrazar la unión sinfónica de las naciones que lo integraban. En un contexto de entreguerras en el que se expandía el discurso trasatlántico de la autodeterminación ${ }^{19}$ el nacionalismo paneuroasiático que promovía Trubetskói y que incorporaba en pie de igualdad a un reguero de pueblos bajo el mismo paraguas debería servir para conferir al nuevo Estado soviético el sentido de unidad necesario para garantizar su viabilidad (Bassin, 2001: 9).

\section{La dialéctica entre el nacionalismo ruso y las minorías étnicas durante el período soviético}

El Imperio ruso se rigió hasta bien entrado el siglo XIX por un sistema de gobierno conocido como "dominio indirecto" que garantizaba un alto grado de autonomía a muchas áreas y comunidades culturales bajo la autoridad del zar. La segunda mitad de la centuria atestiguó la aparición del nacionalismo como movimiento político organizado, hecho que fue seguido del crecimiento de las reivindicaciones nacionales inspiradas en los movimientos democráticos de los imperios austrohúngaro y

\footnotetext{
${ }^{19}$ Este principio figuraba en los “Catorce Puntos" de Woodrow Wilson, un programa expuesto ante el Congreso de los Estados Unidos en enero de 1918 a través del cual el presidente norteamericano pretendía poner fin a la Gran Guerra.
} 
otomano (Tishkov, 1997: 28). Este fenómeno, unido al desarrollo del movimiento obrero, hizo que el mayor problema al que se enfrentara el zarismo a finales de siglo fuera la conciliación de la tradición imperial con el socialismo y las tensiones territoriales de carácter centrífugo. El primer desafío fue contrarrestado parcialmente mediante el ejercicio directo de la violencia por parte de las fuerzas de seguridad y del ejército, mientras que el segundo se abordó a través de una política oficial de rusificación destinada a acabar con la creciente incertidumbre entre el establishment zarista y a calmar el pujante nacionalismo ruso (Pearson, 1991: 13-22).

\subsection{Internacionalismo contra revolución nacional en el bolchevismo temprano}

El asesinato en 1881 del zar Alejandro II por un integrante del Partido de la Voluntad del Pueblo no conllevó la desintegración del gobierno imperial ni su inmediato reemplazo por un régimen socialista. Este hecho fue interpretado por una parte del movimiento revolucionario como la constatación de la imposibilidad de encontrar una "vía rusa hacia el socialismo", y catalizaría a la postre el cisma entre "populistas" y "economistas". Los primeros se mantenían fieles a la ideal de alcanzar el socialismo por la vía directa de la revolución, mientras que los segundos eran partidarios de posponer su asalto al poder hasta que el desarrollo del capitalismo hubiera llegado a un punto óptimo de madurez. Entre los adalides de esta última opción se encontraba Gueorgui Plejánov, teórico y propagandista del marxismo que reelaboraría las ideas hegelianas sobre la influencia de las condiciones ambientales sobre la evolución de la sociedad para acuñar el concepto de "materialismo geográfico". Según este autor, el desarrollo de las fuerzas productivas estaría determinado también por las particularidades del territorio en el que operaban, observación que no aparecía de manera explícita en los escritos de Marx y Engels.

El propio Plejánov impulsó la creación del Grupo de la Liberación de la Fuerza de Trabajo, una de las muchas organizaciones políticas que afloraron en la época y que tenían por objeto la propagación del discurso marxista. La convergencia de algunos de estos grupos cristalizó en 1898 con el nacimiento del Partido Obrero Socialdemócrata de Rusia, pero las tensiones internas pronto se saldarían en una profunda división entre la facción leninista o bolchevique, y la antileninista o menchevique. El partido era en esencia una fusión de socialdemócratas tempranos con el ala más beligerante del marxismo ortodoxo, algo que no era visto con buenos ojos por Lenin (Utechin, 1964: 214-220). El futuro líder soviético se abocaría por consiguiente a la tarea de capturar el aparato del partido, para lo cual se serviría de organizaciones como La Chispa (Iskra), que se encargarían de propagar el mensaje leninista contenido en publicaciones como ¿Qué hacer? o Carta a un Camarada. 
Durante los años de decepción que siguieron a la derrota de la Revolución de $1905^{20}$ la distancia entre bolcheviques y mencheviques se acrecentó, contribuyendo el estallido de la Primera Guerra Mundial a polarizar todavía más el marxismo ruso. Plejánov apoyó al gobierno del zar aduciendo que una victoria alemana impediría el desarrollo industrial de Rusia y pospondría la posibilidad de una revolución proletaria. Por su parte, Lenin rechazó la participación en la Gran Guerra al considerarla una lucha burguesa entre Estados imperialistas que utilizarían el nacionalismo para aplacar las diferencias de clase existentes en sus respectivas sociedades. Sin embargo, durante el transcurso de la guerra el propio Lenin tomaría conciencia de que en un contexto de ruina para el socialismo internacional la idea de esperar la revolución en los países más industrializados era poco más que una quimera (Anderson, 1967: 310-311). De ahí que reorientara progresivamente su discurso a fin de intentar desligar la asociación entre política y economía que en su día hiciera Marx. En su obra El imperialismo, fase superior del capitalismo propugnaría que la revolución se extendiera desde las colonias y los países menos desarrollados, sentando así las bases para el comunismo de un solo país que implantaría tras llegar al poder en la Revolución de Octubre de 1917.

Durante la Guerra Civil los nacionalistas blancos abogarían por una Rusia asimilacionista e indivisible, y contarían con el apoyo de una coalición de potencias occidentales. Halford Mackinder, que había sido designado Alto Comisario para la Rusia Meridional en 1919, abogaría ante el progresivo avance del Ejército Rojo por la creación de un cinturón de Estados tampón destinado a evitar la propagación del comunismo y a limitar las posibilidades derivadas del control omnímodo del Heartland. Esta propuesta de fraccionamiento del espacio ruso, que anticipaba la que años después postularía Zbigniew Brzezinski, resultó finalmente desechada tras la retirada del Imperio británico propiciada en gran medida por el enorme desgaste sufrido durante el transcurso de la Primera Guerra Mundial (Sloan, 1999: 27-28). Por sumar, los bolcheviques apoyarían los movimientos emancipadores entre los pueblos no rusos en un intento por ganar aliados en su cruzada contra el absolutismo. En esta línea, la Declaración de los Derechos de los Pueblos de Rusia, proclamada el 2 de noviembre de 1917, hacía referencia de manera explícita a la igualdad y soberanía de los pueblos de Rusia e incorporaba el derecho a la autodeterminación (Tishkov, 1997: 29). Un año después de la toma del Palacio de Invierno se creaba el Comisariado Popular de las Nacionalidades (Narkomnatz) bajo el mando de Stalin, y el III Congreso del PCUS establecía el principio por el que la República Soviética Rusa se constituía como federación de repúblicas soviéticas nacionales libres (Cucó,

\footnotetext{
${ }^{20}$ Se trató de una ola de protesta política y social que se propagó a amplias áreas del Imperio ruso, y que llevó finalmente al establecimiento de una monarquía constitucional limitada, de la Duma Estatal del Imperio ruso, de un sistema multipartidista y de la Constitución de 1906.
} 
1999: 19-72). A partir de entonces, la política de nacionalidades de la Unión Soviética se regiría por el principio federalizante en un intento por dar solución a los desafíos que emanaban de las regiones periféricas del antiguo Imperio ruso.

\subsection{El pluralismo nacional de la etapa leninista}

La victoria del Ejército Rojo conllevó la paulatina sustitución del discurso pluralista original por otro que, aun reconociendo la condición multiétnica del Estado, la valoraba como una condición temporal que desaparecería a medida que se consolidara una ciudadanía soviética de matriz rusa. La manera en que debía alcanzarse esta "fusión" (sliyanie) era, no obstante, motivo de discrepancia. Stalin prefería un Estado soviético formado por una gran unidad - la Federación Rusa - con agregados subordinados representado a las minorías nacionales. Por su parte, Lenin insistía en una estructura menos rusocéntrica para superar las reticencias de ucranianos, centroasiáticos y transcaucásicos (Huttenbach, 1990: 1-8). En contraposición al principio austromarxista de "autonomía nacional cultural extraterritorial" ${ }^{21}$, sus seguidores defendían un modelo de "autonomía regional" en el que las unidades políticas no se correspondieran con entidades étnicas (Suny, 1993: 85-126). Finalmente, el primer dirigente de la Unión Soviética acabaría optando por una unión de repúblicas separadas que reflejaba las diferencias nacionales ${ }^{22}$, como paso previo a la consecución de una conciencia soviética masiva ${ }^{23}$. El objetivo inmediato que perseguía con ello era neutralizar cualquier antagonismo y promover la "hermandad de naciones" (druyba narodov) en beneficio del proyecto común (Huttenbach, 1990: $1-8)$.

La compartimentación territorial de la federación fue de la mano de un proceso de "nacionalización" o creación de identidades nacionales en cada una de las nuevas repúblicas. En el desarrollo de tal cometido concurrían, según Kaiser (1997: 18), tres hechos concomitantes: la rápida industrialización y la colectivización de la agricultura, que rompían con el localismo decimonónico de las áreas rurales; la

\footnotetext{
${ }^{21}$ El mayor exponente de este pensamiento, Otto Bauer, entendía el socialismo sólo en el contexto de una sociedad democrática, y consideraba que su advenimiento no presuponía el fin de las peculiaridades nacionales, sino la integración del conjunto del pueblo en la comunidad cultural nacional. Véase Cucó (1999: 21).

${ }^{22}$ La división tradicional leninista requería una infraestructura poderosa dedicada a la clasificación y delimitación de grupos nacionales. En total fueron registrados más de 190 de ellos, en base a caracteres lingüísticos y religiosos. La principal dificultad a la que se enfrentó el proyecto se derivaba de la delimitación de las fronteras, puesto que sobre el terreno existía una gran diseminación y mestizaje. Véase Tishkov (1997: 24-43).

${ }^{23}$ Además de la división territorial en naciones jurídicas, se implementó un sistema de clasificación de la población en función de la adscripción étnica e independientemente del lugar de residencia. Véase Brubaker (1996: 23-54).
} 
“indigenización” de los poderes republicanos, consistente en la incorporación de miembros de minorías étnicas a la administración para legitimar así los nuevos poderes y contrarrestar el nacionalismo ruso latente (Taibo, 1999: 106); y la política de "nativización" (korenizatsya), que "contribuyó a la consolidación de la nacionalidad mediante el apoyo a las lenguas vernáculas, la creación de una intelligentsia y unas elites políticas nacionales, y la institucionalización formal de la etnicidad en el aparato del Estado" (Cucó, 1999: 102). Estas medidas, destinadas en un principio al acomodo de la diversidad como paso previo a la creación de una identidad supranacional común, incrementarían la pujanza de los nacionalismos periféricos en lugar de allanar el camino para una futura sovietización.

En la esfera ideológica, la desintegración del Imperio austrohúngaro y la inestabilidad en Europa occidental eran interpretadas por Lenin como una ocasión para la consecución de la victoria final, que sólo podría alcanzarse si el proletariado triunfaba como mínimo en los principales países avanzados. No obstante, tras el fracaso de la revolución luxemburguista en 1923, la nomenklatura moscovita pasaría a abrazar el "socialismo de un solo país" (Carter, 1990: 1-12). La muerte del líder soviético al año siguiente abriría una lucha intestina por la sucesión en la que acabaría imponiéndose Iósif Stalin. La llegada al poder del georgiano representaría un giro paulatino desde el pluralismo leninista hacia una posición en la que el nacionalismo ruso ganaría peso, con el abandono progresivo de la política de indigenización y una interpretación oficial más benigna del pasado zarista.

\subsection{La renacionalización rusa bajo el yugo estalinista}

A resultas del fracaso de las perspectivas internacionalistas, el Partido Comunista Ruso desarrolló progresivamente un antioccidentalismo que fusionaba elementos del mesianismo comunista y el nacionalismo (Carter, 1990: 1-8). La llegada de Stalin a la Secretaria General del PCUS en 1922 confirió al partido un cariz prorruso más acentuado y, si bien en un principio el Zar Rojo continuó la política leninista de indigenización, a principios de los años treinta se embarcó en una carrera de rusificación como vía de sovietización y desnacionalización (Huttenbach, 1990: 18). La política de nativización desplegada hasta entonces había sido concebida con un doble objetivo: contener, canalizar y controlar el potencial disruptivo de la expresión de la nacionalidad mediante la creación de estructuras administrativas y la cooptación de las elites; y promover el debilitamiento de la nacionalidad como componente vial de la vida social (Tishkov, 1997: 24-43). El resultado de la misma, empero, fue el desarrollo y consolidación de identidades político-territoriales que comprometían el proyecto de creación de una personalidad soviética única.

A medida que Stalin consolidó su poder subordinó paulatinamente los intereses de las nacionalidades a los del centro, estableciéndose entre ambos unas relaciones profundamente desiguales que evocaban las existentes en las postrimerías de la era 
imperial. Esta aproximación al nacionalismo ruso fue aplaudida por la hasta entonces oposición eurasianista en el exilio, cuyo ideario acabaría percolando en la doctrina dictada desde el Kremlin. Así, las cosas, la nativización fue reemplazada por campañas antinacionalistas, el derecho a la autodeterminación fue suprimido de facto y cualquier reivindicación autonomista se convirtió en un acto criminal. En este sentido, el "Padre de las Naciones" llegó a afirmar que el mayor peligro que acechaba al proyecto soviético era el nacionalismo periférico de carácter burgués, que se contraponía al internacionalismo proletario bolchevique. El aplastamiento de cualquier tipo de disensión interna alcanzaría su paroxismo en la persecución implacable de todo conato de insumisión o indisciplina emanado desde la periferia. Durante su mandato se procedió a la deportación de decenas de grupos étnicos en su totalidad $^{24}$, motivada frecuentemente en base a conjeturas o meras figuraciones. Las transferencias masivas de población, unidas a la movilidad social ligada a la colectivización de la agricultura y la rápida y forzada industrialización y urbanización tuvieron efectos devastadores en los patrones tradicionales y las prácticas culturales de las nacionalidades, acelerando el proceso de rusificación (Cucó, 1999: 19-72).

El poderoso elemento rusificador de corte conservador propio del estalinismo quedó plasmado en la aprobación de la Constitución de 1936, que fue seguida de medidas como la reintroducción de los uniformes escolares de época zarista o el establecimiento de leyes contra el divorcio y el aborto (Zapater, 2005: 44). La lengua desempeñaría un papel esencial en su afán recentralizador y a finales de los años treinta se introduciría su estudio obligado en todas las escuelas, instituciones de alta educación y administraciones de la URSS. En el plano de la administración territorial, aunque se respetaron las directrices leninistas según las cuales los soviets de las repúblicas debían estar presididos por miembros de las comunidades locales, las secretarías pasaron a ser ocupadas por rusos étnicos, con lo cual se pretendía mejorar la articulación entre centro y periferia a la vez que asegurar la lealtad de las elites (Carter, 1990: 1-8). Pese a que la implantación de medidas de carácter centralista fue la norma durante todo el periodo estalinista, durante los años de la Segunda Guerra Mundial se recurriría de una manera muy especial y sin cortapisas a la exaltación nacional rusa. El proselitismo indispensable para garantizar el éxito en la Gran Guerra Patriótica requería de grandes dosis de emotividad, baza que jugaron

\footnotetext{
${ }^{24}$ Aunque la literatura al respecto es vasta y frecuentemente se aprecian inexactitudes e incluso contradicciones en cuestión de fechas, volúmenes y grupos étnicos deportados, se incluyen entre estos últimos a fineses ingrios (1929-1931 y 1935-1939), kazajos (1933), kalmikos, balkares, karachais, turcos mesjetos, karakalpakos, coreanos (1937), kurdos (1937), judíos persas (1938), polacos (1939-1941 y 1944-1945), fineses de Karelia (1940-1941, 1944), rumanos (1941 y 1944-1953), lituanos, letones, estonios (1941 y 1945-1949), alemanes del Volga (1941-1945), tártaros y griegos de Crimea (1944), chechenos, ingusetios, kabardinos, azeríes, lazes (1944), armenios (1948), griegos del Cáucaso (1949-1950) y japoneses (1951). Para un estudio detallado de esta cuestión, véase Pohl (1999).
} 
las autoridades al rehabilitar a la Iglesia Ortodoxa e invocar de manera recurrente elementos del pasado y la mística del pueblo ruso.

Los progresos del Ejército Rojo en el frente oriental durante la Segunda Guerra Mundial serían observados con recelo por las potencias aliadas. En el punto álgido de la contienda un anciano Halford Mackinder daba fe de la preocupación creciente instalada en las cancillerías occidentales respecto a la posibilidad que la Unión Soviética acabara haciéndose con el control de Alemania y Europa Oriental. En su artículo de 1943 titulado "The Round World and the Winning of the Peace” advertía que la consumación de estos hechos no sólo convertiría a la URSS en la mayor potencia terrestre del mundo, sino que le garantizaría el control del emplazamiento estratégico más valioso desde el punto de vista defensivo (Mackinder, 1943). Su tercera versión del Heartland coincidía en gran medida con el territorio soviético, pero dejaba sabiamente difuminados los márgenes en los extremos oriental y occidental para subrayar de manera particular la importancia del control posbélico del área intersticial entre la Unión Soviética y Alemania. Los vaticinios del geógrafo británico se cumplirían parcialmente tras la cuasi-absorción de China en el bloque soviético euroasiático en 1949 y la creación tanto del COMECON como del Pacto de Varsovia en 1949 y 1955 respectivamente.

\subsection{El espejismo pluralista de la era Jruschov}

El ascenso tras la muerte de Stalin en 1953 de Nikita Jruschov a la Primera Secretaría del PCUS significó un cambio de rumbo en la política soviética tanto a nivel doméstico como internacional. El inevitable cisma entre China y la URSS y el inicio de la carrera nuclear representaron sendos puntos de inflexión en la interpretación geopolítica del mundo contemporáneo y reavivaron el debate sobre la vigencia del Heartland. En opinión de algunos autores el progreso tecnológico erosionaba la preeminencia de geografía como variable clave en la formulación de la política exterior, mientras que otros aducían que el factor disuasorio abolía de facto cualquier avance armamentístico y seguía otorgando validez a la máxima geoestratégica que imperaba en la era prenuclear (Hauner, 1992: 225-321). En el plano interno la apertura afectó también a la política de nacionalidades, como quedaría de manifiesto en el discurso que el líder soviético pronunció a principios de 1956 en el XX Congreso del PCUS. En él denunció las graves violaciones cometidas en materia de gestión de las nacionalidades durante el periodo estalinista, y proclamó el "florecimiento" (rastsvet) de las culturas de los pueblos no rusos. El rechazo a las políticas homogeneizadoras de tintes prorrusos se acompañaría durante su primer año de mandato de la rehabilitación de algunos de los pueblos que el Zar Rojo había 
deportado $^{25}$ durante su etapa en el poder (Taibo, 1999: 143). En el plano de la administración territorial, Jruschov se propuso el establecimiento de un sistema de "dominio indirecto" de inspiración prerrevolucionaria, que unido a la mejora de las restricciones a la expresión étnica favoreció la aparición de elites políticas nacionales - particularmente en Transcaucasia y Asia Central- y la pronta gestación de un sistema corrupto basado en el clientelismo, el favoritismo y el soborno (Suny, 1993: 118).

El tímido proceso de descentralización —más nominal que efectivo- y el escaso éxito de la política económica desencadenó un creciente descontento en un sector importante de la sociedad soviética que dio origen a la génesis de dos potentes corrientes de nacionalismo ruso opuestas a la política oficial del Kremlin: una antiestalinista, de carácter liberal y anticomunista, que buscaba recrear el pasado idílico al que evocaban los primeros eslavófilos; y otra neoestalinista, de cuño autoritario, conservador e imperialista, que recelaba del tímido proceso liberalizador emprendido y censuraba la reprobación oficial del legado del "Padre de las naciones" (Carter, 1990: 1-12). Las demandas en pro de un cambio de rumbo acabarían siendo abrazadas por el propio aparato del PCUS, lo cual obligaría a un golpe de timón que se escenificaría en el XXII Congreso de 1961 con la proclamación de un nuevo estadio en las relaciones nacionales internas basado en el fomento de su convergencia (sbliyeniye) para la consecución de la "fusión final” (sliyanie) en un solo pueblo (Taibo, 1999: 34-143).

\subsection{El proyecto brezhneviano del "homo sovieticus"}

La llegada de Brézhnev a la Primera Secretaría del PCUS en 1964 supuso un endurecimiento de la política de "sovietización” emprendida por su antecesor en los años previos al golpe de Estado que lo apeara del poder. El máximo exponente de este impulso recentralizador vería la luz en el XXIV Congreso del Partido en 1971, cuando el líder soviético señaló el nacimiento del “pueblo soviético”. Este concepto de nuevo cuño debería desplazar progresivamente la multitud de apelativos con que se identificaban cada una de las etnias que integraban la Unión y acabar así con su efecto disgregador. Al mismo tiempo, albergaba implícito un fortalecimiento del nacionalismo ruso que resultaba indispensable en un escenario demográfico marcado por el crecimiento relativo de los pueblos de cultura no eslava (Taibo, 1996: 40). Así las cosas, el idioma ruso se consolidaría como lingua franca de la Unión, y otros elementos de su cultura como la música, la literatura, el arte o el folklore

\footnotetext{
${ }^{25}$ A la muerte del dictador se contabilizaban 2.753.356 “colonos especiales” (spezposelentsy), sin incluir los encarcelados, ejecutados o muertos por inanición o enfermedad. Véase Tishkov (1997: 24-43).
} 
pasarían a utilizarse a modo de sinécdoque como referentes de la cultura soviética popular (Huttenbach, 1990: 1-8).

La Constitución de 1977 reafirmaba la voluntad unitaria del Estado y hacía del “centralismo democrático" el principio rector de la política de Moscú. Entre otros cambios, la nueva Carta Magna ampliaba las competencias administrativas del centro, reducía el derecho de autodeterminación a mera retórica e ignoraba cualquier referencia a la capacidad de las repúblicas a disponer de ejército propio (Taibo, 2000: 29). Estado, partido y ejército ${ }^{26}$ se convertían de facto en los pilares para la consecución del homo sovieticus (sovietsky chelovek). Los tres aparatos se nutrirían de las elites de pueblos no rusos a condición de que se adhirieran sin reserva a los preceptos constitucionales y contribuyeran a catalizar el proceso de transformación social (Carrère d'Encausse, 1984: 202). Se confiaba de este modo la responsabilidad de sectores clave a cuadros nacionales que habían sido cooptados para aprovechar su proximidad a la realidad de las diferentes repúblicas sin descuidar por ello su total supeditación a la administración central, ante la cual debían rendir cuentas ${ }^{27}$.

\subsection{El giro aperturista de Gorbachov y el resurgir de las naciones}

El interregno de Yuri Andrópov y Konstantin Chernenko al frente del PCUS abrió paso a un periodo de reformas en lo económico (perestroika) y de apertura en lo político (glasnost) de la mano de Mijaíl Gorbachov. En los primeros años de su mandato, no obstante, apenas se introdujeron cambios en el ámbito de la política de nacionalidades respecto al periodo anterior a 1985. Hasta esa fecha, el poder central había sido lo suficientemente fuerte como para controlar las administraciones locales y suprimir al mismo tiempo los intentos organizados de articulación de movimientos políticos nacionalistas periféricos ${ }^{28}$. Ahora bien, tan pronto como el

\footnotetext{
${ }^{26}$ De acuerdo con los postulados oficiales, el servicio militar debería contribuir a alejar las solidaridades nacionales. En la realidad no hizo sino favorecer la toma de conciencia por parte de los integrantes de las minorías nacionales del proceso de asimilación que estaba en marcha y de la distancia ente la teoría de un ejército supranacional, y la realidad de una armada rusa. Véase Carrère d'Encausse (1984: 201-202).

${ }^{27}$ La constatación de este hecho podría, no obstante, inducir al lector a pensar que las minorías nacionales ganaron presencia en los puestos de alta responsabilidad de la administración soviética. El estudio diacrónico de su composición revela, en contrapartida, que el porcentaje de rusos en el Comité Central del PCUS ascendió desde un 57\% en 1966 hasta un 68\% en 1981, su presencia en el Politburó pasó de un 54,5\% a un $71,5 \%$ en el mismo periodo, y más de un $90 \%$ de los oficiales de las fuerzas armadas eran rusos, bielorrusos o ucranianos en las postrimerías de la era brezhneviana. Ello pondría de relieve el hecho que las autoridades soviéticas juzgaban a parte de la masa humana soviética como poco digna de confianza e ineficaz. Véanse Taibo (1999: 176) y Kennedy (2004: 782).

${ }^{28}$ El censo de 1989 registraba entre los 290 millones de ciudadanos de la URSS a 22 nacionalidades con más de un millón de miembros y 33 por encima de cien mil. Asimismo, contabilizaba un total de 107 lenguas,
} 
aparato estatal perdió mordida la etnicidad como base de la solidaridad grupal y el nacionalismo étnico como doctrina política no tardaron en desafiar el statu quo (Tishkov, 1997: 24-43). Se ponía así en evidencia la incapacidad de uno los Estados más poderosos de la historia para crear una nueva identidad nacional, lo que probaría a su vez la perdurabilidad y la vitalidad de la nación más allá —y a pesar- del Estado (Castells, 2003: 64).

Las reivindicaciones separatistas vigorizaron también un movimiento nacionalista ruso que se había incubado durante décadas al abrigo de la sovietización oficial promovida por el Kremlin. El elemento central de su discurso era la idea de que Rusia había contribuido de manera altruista al desarrollo de los restantes pueblos de la URSS y éstos eran incapaces de reconocer el esfuerzo realizado por el hermano mayor de la federación. Este premisa impregnaría la práctica totalidad de las manifestaciones políticas del momento, desde el reformismo prodemocrático al conservadurismo autoritario (Taibo, 1999: 205). Este último atribuía las veleidades centrífugas al creciente desorden y la permisividad brindada por el nuevo líder soviético. Las reformas de carácter occidentalizador chocarían, según este sector, con la idiosincrasia autárquica y antieuropeísta del pueblo ruso que en su día describieran los primeros eslavófilos.

Aunque Gorbachov mantuvo durante los primeros años el concepto brezhneviano de "pueblo soviético", el papel que ocupaba el pueblo ruso en la configuración del mismo resultó mucho menos destacado que en épocas pasadas (Taibo, 2000: 86-88). En 1989, el líder soviético se retiraba públicamente del objetivo de fusionar los pueblos de las repúblicas en una unidad cultural metanacional (Huttenbach, 1990: 1-8). Entre los cambios asociados a este nuevo giro se volvía al multiculturalismo cultivado por los bolcheviques en la primera mitad de los años veinte. De esta manera, entonando el principio de "a cada nación su lengua”, se procuraba la restauración de los idiomas nacionales en un intento por satisfacer las demandas procedentes de la periferia (Cucó, 1999: 19-72). En el capítulo administrativo, empero, la poca diferenciación orgánica entre la RSFSR y la URSS ${ }^{29}$ y la composición preponderante de rusos étnicos en los más altos puestos de la administración y el ejército no dejaron de alimentar hasta su disolución la ambigüedad sobre el carácter del Estado soviético como una federación multinacional o un Estadonación ruso (Brudny, 2000: 1-27).

En suma, puede concluirse que el bolchevismo fue inconsistente defendiendo la "nativización” y "florecimiento" de las culturas nacionales a la vez que promoviendo la "obliteración de sus caracteres distintivos" (stiranie), la "convergencia"

además de distinguir minorías religiosas como la musulmana, la budista y la judía. Para mayor información sobre esta cuestión véase Sheey (1991: 56-88).

${ }^{29}$ Hasta 1990 la RSFSR era la única república soviética sin Partido Comunista, KGB o Academia de Ciencias propia. 
(sbliyenie) y la "fusión” (sliyanie) en un sólo pueblo (Suny, 1993: 85-126; Fragner, 2001: 12-33). El régimen conservaba poder para decir qué era una expresión patriótica permisible y qué era nacionalismo pernicioso, y esta frontera cambió constantemente a lo largo de las siete décadas de existencia de la URSS. Paradójicamente, la nomenklatura soviética nunca cesó de producir nacionalismo de matriz rusa como instrumento de movilización de masas. Este modelo, en principio incompatible con el marxismo, se fundía con el mismo en una combinación ${ }^{30}$ que tuvo un papel primordial en la génesis del movimiento anticolonial posterior a la Segunda Guerra Mundial así como en el del tercermundismo (Suny, 1993: 85-126). Pese a que la Unión Soviética no fue concebida en origen como un Estado-nación ordinario, sino como la primera piedra de un edificio socialista multinacional (Suny, 1993: 85-126) cuyo modelo debería exportarse al resto del mundo, la retórica bolchevique se apoyó sistemáticamente en el nacionalismo ruso usándolo como patrón para la consecución del homo sovieticus así como para legitimar e incluso conferir una dimensión cuasi providencial al régimen. Este sentimiento cristalizaría en un movimiento que rechazaría el concepto cívico-ideológico de "pueblo soviético" y acabaría impregnando gran parte de las opciones políticas que conformaron el nuevo panorama político ruso de Posguerra Fría.

\section{El nacionalismo ruso en el pensamiento geopolítico de Posguerra Fría}

El nacionalismo "en una forma u otra [...] domina la totalidad del espectro electoral" (Laruelle, 2008b: 40) ruso desde $1993^{31}$ y constituye "uno de los elementos centrales del consenso social que ha emergido entre las autoridades y la sociedad en los últimos años” (Laruelle, 2008b: 6). El aparato del Estado contribuye a propagar esta ideología mediante el impulso de programas escolares de educación patriótica, la elevación al rango de "nacional" de determinados componentes de la ortodoxia rusa y la puesta en marcha de campañas publicitarias que copan el espacio mediático ruso. El mensaje que procuran inocular las autoridades a través de los resortes que les brinda el poder se fundamenta en la idea de que existe una continuidad histórica del Estado ruso independientemente de las rupturas políticas acontecidas a lo largo de los siglos. La esencia de Rusia no yacería pues, en el régimen político instalado en el Kremlin, sino en la grandeza de su idiosincrasia, su relación con el "extranjero

\footnotetext{
${ }^{30}$ Un ejemplo ilustrativo es la diferenciación entre naciones oprimidas y opresoras, reemplazando "clase" por "nación". Otro es el concepto leninista de "dos caminos" ( $d v a$ potoka), que diferenciaba las tendencias positivas y progresistas dentro de la cultura nacional de las conservadoras y reaccionarias.

${ }^{31}$ La Constitución aprobada tras la crisis de septiembre y octubre de 1993 abría una nueva etapa en la que el Kremlin abandonaría el occidentalismo para abrazar un discurso en el que el nacionalismo ganaría paulatinamente relieve.
} 
cercano”32 (bliyneye zarubezhye) (Light, 2003: 56), su lugar en el escenario internacional y el sentido providencial de su misión civilizadora (Laruelle, 2008b: 44-59).

La ubicuidad del pensamiento nacionalista podría llevarnos a interpretar tal doctrina como un corpus homogéneo e inmutable que viene impregnando la totalidad del discurso político desde la desintegración de la URSS. Resulta perentorio, empero, hacer algunas salvedades a esta presunción. En primer lugar, si bien es cierto que la mayoría de partidos políticos, organizaciones cívicas, think tanks e intelectuales comulgan del ideario nacionalista, existe espacio para corrientes que reniegan del mismo. En segundo lugar, el concepto "nacionalismo" es un paraguas bajo el que conviven multitud de tendencias en continua mutación y con principios frecuentemente contrapuestos. Por último, y como se ha puesto de relieve en apartados anteriores, este credo no siempre ha ocupado una posición de centralidad en la política dictada desde Moscú sino que puntualmente ha sido relegado al ostracismo $\mathrm{y}$ en infinidad de ocasiones se ha utilizado atendiendo a criterios de estricta conveniencia. Así las cosas, Laruelle (2008b: 44-59) clasifica el nacionalismo ruso de Posguerra Fría en tres grandes conjuntos con diferente grado de penetración en la opinión pública y en los círculos decisorios: los aislacionistas, los defensores de los rusos del extranjero cercano y los adalides de la dominación sobre el espacio exsoviético ${ }^{33}$.

La primera categoría es frecuentemente clasificada como "etnonacionalista" e incorpora en su ideario el abandono de cualquier tipo de veleidad sobre el espacio euroasiático en favor de una política aislacionista. De acuerdo con sus valedores, Rusia habría financiado el desarrollo cultural y económico de los otros pueblos soviéticos, hecho que aprovecharían estos últimos para ganar la independencia. La organización territorial de la Federación Rusa, "garantista" con los derechos de las minorías étnicas, supondría un riesgo real que podría precipitar una nueva implosión del Estado análoga a la que acabó con la Unión Soviética. De ello se desprendería la necesidad de implementar una política centrípeta de "nacionalización" de la Federación para evitar males mayores derivados la falta de cohesión interna. Esta corriente, de marcado carácter ultranacionalista, se distingue también por una fervorosa islamofobia, un antisemitismo galopante y una profunda aversión hacia los ciudadanos de origen caucásico y/o centroasiático, a quienes se les atribuye un supuesto aumento de la criminalidad. Se adscriben a esta órbita una parte del profuso contingente de grupos violentos de orientación filonazi ${ }^{34}$ así como algunos

\footnotetext{
${ }^{32}$ Acuñado en marzo de 1992 por Shelov-Kovedayev, entonces ministro ruso de Asuntos Exteriores, el concepto de "extranjero cercano" se refiere al conjunto de las catorce repúblicas exsoviéticas a excepción de Rusia. Véase Velliste (1993) y Charillon (2004).

${ }^{33}$ Para un estudio detallado del universo nacionalista ruso véanse Laruelle (2009) y Zapater (2005: 273).

${ }^{34}$ Según el Consejo de Europa, a finales de 2013 se contabilizaban unos 50.000 skinheads en la Federación Rusa. En el mismo año la ONG Sova elevaba a 20 el número de muertos y a 173 el de heridos víctimas de la
} 
partidos políticos sin representación parlamentaria que reformulan y adaptan las bases del nacionalsocialismo alemán a la realidad rusa ${ }^{35}$.

El segundo conjunto posee un perfil menos extremista, y a diferencia del anterior abandera la defensa de los rusos étnicos residentes en el extranjero cercano. Su modelo bebe de las ideas de los eslavófilos clásicos (Dugin, 2014) y preconiza el establecimiento de relaciones bilaterales asimétricas entre una Rusia fuerte y unos Estados postsoviéticos débiles. Asimismo, muestra rechazo a cualquier regulación multilateral fundamentada en la equidad que emane de un marco institucional supraestatal. La policromía de esta categoría queda reflejada en la vinculación de partidos de tan diferente etiología como el neofascista Partido Nacional Republicano de Rusia, desaparecido a finales de los noventa, el "rojipardo" Partido Nacional-Bolchevique, convertido en 2010 en La Otra Rusia, y la coalición izquierdista Rodina, que pasaría en 2006 a integrar Rusia Justa.

El tercer grupo es el más ampliamente representado en las instituciones rusas y puede considerarse también imperialista en la medida en que busca recuperar el liderazgo en la región como vía para restablecer el estatus perdido de gran potencia. La mayoría de intelectuales y dignatarios de Moscú coinciden al estimar que Rusia no será capaz de conseguir los objetivos primarios de estabilidad interna y desarrollo económico sin antes abordar los desafíos que se presentan en su extranjero cercano. Para ello resulta indispensable la implementación de una estrategia omnicomprensiva que aborde la totalidad del espacio euroasiático como un único ente (Tsygankov, 2003: 102). Precisamente ésta es la premisa desde la que opera el neoeurasianismo, una corriente que agrupa a una amalgama de concepciones geopolíticas que van desde la reconstitución de la URSS a la instauración de un imperio continental, pasando por el refuerzo de los lazos económicos o la mera coerción política en el antiguo espacio soviético. La prevalencia actual de esta línea de pensamiento en la palestra política rusa la hace merecedora de un apartado propio para su estudio más detallado.

\subsection{El neoeurasianismo o el renacer de las aspiraciones imperiales de Rusia}

Las ideas eurasianistas reaparecieron durante el periodo soviético de la mano del Pamiat $^{36}$, aunque fuera de círculos especializados no se popularizaron hasta los años

violencia racista. Véanse European Comission Against Racism and Intolerance (2013) y Sova. Center for information and analysis (2014).

${ }^{35}$ Entre éstos destacan el Partido Nacional del Pueblo y la Unidad Nacional Rusa. Ambos preconizan un racismo biológico que incluye medidas como la eugenesia o la prohibición de matrimonios mixtos.

${ }^{36}$ Creado en el año 1979, inicialmente fue una sociedad histórica y literaria vinculada al Comisariado Popular de la Aviación Industrial de la URSS que llegó a ganarse el apoyo de miles de simpatizantes debido 
finales de la perestroika. Consolidado ya en los albores de los noventa, el nuevo eurasianismo expresaba su preocupación ante la deriva occidentalizadora adoptada por el Kremlin y se erigía como único garante de la preservación de los intereses del pueblo ruso. Se perfilaba de esta manera como una respuesta frontal a los planes de ampliación de la OTAN en el espacio exsoviético, a los estragos sociales producidos por la salvaje liberalización de la economía, y al galopante proceso de globalización, que habría minado con el consumismo, el egoísmo y el libertinaje el hasta entonces incorrupto espíritu patrio. Lejos de constituir un credo monolítico, la imprecisión y el atractivo de sus postulados lo llevaron a convertirse en uno de los conceptos más utilizados del volátil arsenal ideológico postsoviético (Bassin, 2008: 279).

Si bien la doctrina actual respeta en líneas generales la esencia del corpus teórico original, merece la pena destacar tres diferencias básicas respecto a la propuesta de los padres fundadores. La primera de ellas alude a la posición de los diferentes grupos étnicos en el espacio euroasiático. Aunque el neoeurasianismo ruso reconoce a título nominal la diversidad religiosa y nacional del mismo, en la práctica destila un ferviente nacionalismo de carácter etnicista y se arroga en exclusiva el rol de líder en la región. Ello va unido a un elevado grado de desconfianza hacia el mundo musulmán y a una menor simpatía hacia los pueblos mongoles y centroasiáticos, cercanos desde el punto de vista histórico, geográfico y cultural. En su lugar, adquiere mayor preeminencia la región de Asia-Pacífico, más apetecible debido a su pujanza económica. La segunda diferencia corresponde al nivel de la teoría política. Mientras que el eurasianismo clásico está fuertemente influido por la ideas revolucionarias de inspiración fascista que atribuyen a la humanidad la capacidad de cambiar gracias al poder de su voluntad, la mayor parte de sus manifestaciones contemporáneas desechan tal eventualidad y adoptan una postura más incrédula respecto a las posibilidades reales de transformación social (Laruelle, 2008a: 4-5). En último término, tras la caída del telón de acero también proliferaron variantes reformuladas de esta escuela en el seno de otras comunidades nacionales dentro y fuera de los límites de la antigua Unión Soviética ${ }^{37}$. Ello hizo que la realidad de Eurasia se tornara si cabe más polisémica, y que incluso desde la periferia turcomusulmana se alzaran voces que osaban cuestionar la indiscutida posición de centralidad de Rusia en el continente euroasiático (Billington, 2004: 68-72). Sin em-

a su vocación filantrópica. En 1985 su liderazgo cayó en manos de ultranacionalistas y pasó a convertirse en un bloque opositor al régimen comunista.

${ }^{37}$ Destacan la de Mintimer Shaimíev, primer presidente de la república autónoma rusa de Tataristán y, especialmente, la de Nursultán Nazarbayev, presidente de Kazajistán desde 1989. Este último fue el impulsor de la Universidad Euroasiática Nacional L. N. Gumilev de Astaná y concibió la Unión Euroasiática, un proyecto político inspirado en la Unión Europea que integraría varias exrepúblicas soviéticas. Para un análisis detallado de esta propuesta véase Biryukov (2013). 
bargo, este hecho podría calificarse de anecdótico, puesto que tal y como apunta Kaplan (2012: 176-178) el eurasianismo sigue contando con un apoyo residual en la mayoría de repúblicas centroasiáticas, y una mera llamada a la geografía —como es el eurasianismo - no es suficiente para ganarse su adhesión a un proyecto común.

Uno de los promotores del renacimiento eurasianista fue el historiador y antropólogo Lev Gumilev, autor entre otras obras de La ciencia de ethnos. En ella desarrollaba la teoría de la "etnogénesis", que establecía que el factor determinante de los grandes cambios en la historia no era la raza ni la clase social, sino un tipo particular de "pasión étnica y emocional” (passionarnost) capaz de aglutinar a gentes de orígenes diversos. El eurasianismo representaría, a su juicio, una inyección de esta pasión que permitiría crear un "superethnos" por encima de diferencias fenotípicas o culturales. Gumilev criticaría la equiparación entre rusos y soviéticos al considerarla un escollo para la formación de una futura unión de naciones, lo que le valdría las críticas del nacionalismo ruso más conservador, que defendía la pureza de la raza y no estaba dispuesto a admitir su ascendencia mongol, huna o tártara (Zapater, 2005: 108-117).

Más en línea con el discurso de la Nueva Derecha, Vadim Tsymburski rescata la asociación entre objetivos políticos e imágenes geográficas que realizara en su día Mackinder y concibe a Rusia como una "isla civilizacional” rodeada de un cinturón de países o "Gran Limítrofe" que la separaría a modo de cordón sanitario de las grandes potencias europeas y asiáticas. Se trataría éste del mayor escenario geopolítico del siglo XXI, por lo que Moscú debería preservar por todos los medios su homeostasis y aprovechar la posición de centralidad en el continente para liderar la resistencia contra la penetración euroatlántica. Por su parte, Aleksandr Panarin argumentaba a mediados de los noventa que Rusia debería jugar en Eurasia un papel similar al que desempeñó Estados Unidos en el Atlántico Norte tras la Segunda Guerra Mundial. El filósofo ruso abogaba por una estructura neobizantina que combinara el autoritarismo político con el pluralismo cultural, en contraste con el pluralismo político y uniformidad cultural de Occidente (Billington, 2004: 72-80). Vadim Koyinov iría todavía más lejos al afirmar que la idea eurasianista era previa a la Revolución de Octubre y, por tanto, plenamente compatible con el nacionalismo ruso, tanto de corte estalinista como neoimperial. En su opinión los rusos constituían la única matriz de Eurasia, razón que les facultaba para apostar por el imperialismo en lugar de la orientalización pregonada por el movimiento original de entreguerras (Laruelle, 2008a: 5).

En el escenario de Posguerra Fría ningún partido político con representación parlamentaria abraza de manera íntegra los planteamientos neoeurasianistas, aunque como se verá a continuación su discurso vaporoso impregna en mayor o menor medida todos los grupos de la Duma. El "entrismo ideológico" no se limita a los 
cuerpos estatales ni a la esfera política en su acepción más restrictiva, sino que también alcanza la intelectualidad, la academia y el mundo de la cultura, además de gozar de un amplio respaldo entre la opinión pública rusa ${ }^{38}$. La diversidad de esta doctrina y el polimorfismo que la singulariza hace que resulte perentoria una categorización de sus múltiples manifestaciones para el mejor discernimiento de los matices y contradicciones que la dotan una condición única (Laruelle, 2008a: 208).

\subsection{Principales escuelas eurasianistas de pensamiento geopolítico}

Los años que siguieron a la desaparición de la Unión Soviética presenciaron la emergencia de diversas escuelas de pensamiento que intentaban definir Eurasia así como determinar los principales objetivos de Moscú en la región. Al contrario de lo vaticinado por algunos políticos y académicos, Rusia continuó interesada en asegurar su presencia política, económica y cultural en este espacio, y la mayor parte de sus elites se mostraron convencidas de que el recién creado Estado no sería capaz de afrontar con éxito sus desafíos internos más apremiantes sin antes dar respuesta a aquellos que emanaban del antiguo espacio soviético. Lejos de constituir un bloque homogéneo, Tsygankov (2003) distingue cuatro grupos dentro del movimiento euroasiático que responden a orientaciones teóricas diferentes: los geoeconomicistas, los civilizacionistas, los expansionistas y los estabilizadores. Además de estos, en el presente apartado se incluirá también la escuela occidentalista, una rara avis crítica con la filosofía eurasianista y de gran influencia en los primeros compases de vida de la Federación Rusa ${ }^{39}$.

El occidentalismo o internacionalismo institucional se encuentra íntimamente ligado al Nuevo Pensamiento de la segunda mitad del mandato de Gorbachov ${ }^{40}$. Esta innovadora concepción política conllevó en la práctica un giro prooccidental

\footnotetext{
${ }^{38}$ La ambigüedad inherente a esta corriente salta a la vista en los estudios de opinión. Mientras que por una parte el $77 \%$ de los rusos serían favorables al mantenimiento o refuerzo de los vínculos políticos con las antiguas repúblicas soviéticas y un 56\% consideraba a Estados Unidos como principal enemigo, por otra el $71 \%$ de los encuestados apoyaba el estrechamiento de las relaciones con Occidente. Véase Levada Analytical Center (2013).

${ }^{39}$ Antes de pasar al estudio de cada una ellos conviene apuntar que esta división representa una clasificación ideal, siendo por tanto una simplificación de la realidad que será sin embargo útil para una mejor comprensión de la misma. Asimismo, aunque la mayoría de analistas coinciden en los criterios que deberían ser usados para distinguir las diferentes corrientes, existe discrepancia respecto a su número y los términos que las definen. Otras alternativas a ésta son las de Wight (1992: 1-48), Dawisha y Parrott (1994: 199-202), Clunan (2009), Smith (1999: 481-494) y Jackson (2003: 27-50).

${ }^{40}$ En su obra Perestroika: New Thinking for Our Country and the World, el último líder soviético incidía en la prioridad de la cooperación internacional como medio para disipar el fantasma de una hipotética de conflagración nuclear. Asimismo, proclamaba la importancia de los valores comunes a toda la humanidad. Véase Gorbachov (1988).
} 
mediante el cual Moscú pretendía convertirse en miembro activo de las instituciones políticas y económicas internacionales. Se culminaban de este modo los intentos de aproximación entre la Unión Soviética y Estados Unidos iniciados por Jruschov y Brézhnev, aunque la magnitud de los cambios y el grado de ambición de los mismos "no tenían prácticamente precedentes en la historia de la política exterior de Rusia” (Tsygankov, 1997: 247-268). Tras el fin del periodo soviético el primer presidente ruso Boris Yeltsin y el ministro de asuntos exteriores Andréi Kozyrev recogieron el testigo del padre de la perestroika y anunciaron que la Federación Rusa iniciaría un proceso de acercamiento y cooperación con Occidente basado en valores compartidos como la democracia, los derechos humanos y el libre mercado. En su ideario incluían una definición cívica de la ciudadanía rusa y rechazaban la búsqueda de una única "idea nacional” que justificara la recreación del imperio (Tsygankov, 1997: 250).

Respecto a la percepción sobre la esencia misma del acervo ruso, esta corriente consideraba al nuevo Estado parte integral de Occidente desde el punto de vista cultural e histórico, rechazando por consiguiente la idea eurasianista de puente intercultural entre el continente asiático y el europeo. La sucesora de la URSS habría perdido de manera irrecuperable el papel de "superpotencia", pero ello no sería un obstáculo insalvable para la consecución de los objetivos primordiales de prosperidad económica y paz social ${ }^{41}$. En el extranjero cercano sus políticas deberían fundamentarse en los principios de igualdad, cooperación mutua y no injerencia a la par que declinar cualquier veleidad neoimperial. La primera preocupación en la región sería ahora lograr la pacificación de los conflictos que habían eclosionado tras la caída del telón de acero, pero la estrategia para conseguirla ya no pasaría por el uso unilateral de la fuerza, sino que en su lugar se contemplaría la negociación y la intervención de organismos multilaterales (Jackson, 2003: 34; Tsygankov, 1997: 247-268). Un segundo paso apuntaría a la paulatina integración motu proprio de las exrepúblicas soviéticas con vistas a la creación de una confederación de Estados en un horizonte próximo ${ }^{42}$.

Por su parte, el geoeconomismo otorga preponderancia a los factores geoeconómicos sobre los geopolíticos y considera que la identidad rusa vendría determinada por la intersección de influencias económicas y culturales en el corazón del continente euroasiático. De acuerdo con esta escuela de pensamiento el mundo es crecientemente interdependiente y culturalmente pluralista, razón por la cual las principales amenazas que se ciernen sobre la heredera de la Unión Soviética no son de

\footnotetext{
${ }^{41}$ A pesar de la pérdida del estatus de “superpotencia”, un sector liderado por el ministro Kozyrev todavía defendía que las características geográficas, demográficas, económicas y políticas de la Federación acabarían devolviéndole a medio plazo una posición rebajada de "gran potencia”.

${ }^{42}$ Un primer hito en este camino fue la creación de la Comunidad de Estados Independientes (CEI) por parte de Rusia, Bielorrusia y Ucrania el 8 de diciembre de 1991.
} 
naturaleza político-militar sino económica. El objetivo primordial en materia de seguridad pasaría por garantizar la prosperidad económica y el desarrollo social del Estado, un escenario de estabilidad que requeriría para su consecución de orden político dentro y fuera de sus fronteras. La receta para conseguirlo debería basarse en la puesta en marcha de macroproyectos económicos impulsados por partenariados público-privados que integraran a agentes occidentales y asiáticos.

En el escenario de Posguerra Fría la corriente civilizacionista se asocia al neosovietismo o comunismo euroasiático, que evoca con nostalgia un pasado glorioso en el que el pueblo ruso rebosaba de orgullo y gozaba de respeto internacional. A la hora de definir y legitimar su discurso es crucial la consideración de tres aspectos. El primero de ellos hace referencia a los valores patrióticos que deberían alimentar al pueblo ruso. Estos abrazarían el heroísmo de acontecimientos como la Revolución de Octubre, la rápida industrialización de los años treinta, la victoria en la Gran Guerra Patriótica o los éxitos de la carrera espacial. Asimismo, rehuirían el internacionalismo leninista, el reformismo poststalinista y la apertura hacia el cosmopolitismo occidentalizador de la perestroika. El segundo punto alude a la idiosincrasia comunista de la nación rusa, algo que se remontaría al atavismo comunitarista tribal y que contrastaría con los valores burgueses y el individualismo de mercado liberales. El tercer y último aspecto apunta al restablecimiento de Eurasia esgrimiendo la retórica de una "reincorporación voluntaria”. Esta visión no está exenta de contradicciones puesto que invoca la hermandad en pie de igualdad de las naciones a la vez que atribuye a Rusia el papel de primus inter pares en el nuevo proyecto político, sin descartar en ningún momento el recurso a la coerción político-económica (Smith, 1999: 481-494).

Una de las personalidades más representativas de esta escuela de pensamiento es Guennadi Ziugánov, líder del Partido Comunista de la Federación Rusa (PCFR) ${ }^{43}$. Según el mismo, Rusia es una unidad política, económica y cultural euroasiática cuya perdurabilidad dependerá de su capacidad de poner coto a las pretensiones occidentales de construir un "nuevo orden mundial" basado en el egoísmo, el materialismo y la inmoralidad. La relación con Occidente es por tanto vista como un juego de suma cero en el que si Moscú no logra imponerse y consolidarse como contrapeso al primero correrá el riesgo de convertirse en colonia suya (Ziugánov, 1997). Así, el líder comunista sustituye el mantra comunista de la "lucha de clases" por el "choque de civilizaciones" huntingtoniano. La receta para superar la hostilidad exterior pasa, pues, por la promoción de la "autarquía político-económica" (samodostatochnost) y el cultivo de un "pragmatismo saludable” que incluiría el

\footnotetext{
${ }^{43}$ Fundado en 1993, se declara legatario del Partido Comunista de la RSFSR, organización política creada en 1990 por opositores del "ala dura” a las reformas de Gorbachov y prohibido por Yeltsin después del golpe de Estado de agosto de 1991. Su ideario sui generis fusiona viejos valores del marxismo-leninismo con planteamientos nacionalistas y tradicionalistas.
} 
establecimiento de un cinturón de seguridad alrededor de sus fronteras. En relación a este último punto, Ziugánov aboga por la restauración voluntaria del antiguo espacio soviético y recalca la necesidad de apoyar a la diáspora rusa. Por último, considera que las capacidades militares son cruciales para recuperar su estatus perdido de "gran potencia" (deryava) así como en la organización de Eurasia en función de los intereses estratégicos y los valores culturales rusos (Jackson, 2003: 27-50).

El expansionismo revolucionario se inspira en la llamada de Lenin y Trotski a la revolución mundial para formular un corpus ideológico que propugna la expansión territorial como mejor opción para garantizar la seguridad del Estado. En la reformulación expansionista dicha revolución es, no obstante, de corte conservador y debería culminar con una Pax Eurasiática de carácter neototalitario. Al igual que los civilizacionistas, desde esta corriente se descarta la cooperación internacional como principio para la consecución de cualquier objetivo político y se insiste en la necesidad de que Rusia ocupe el vacío dejado en el continente euroasiático tras el hundimiento de la Unión Soviética antes que el sempiterno enemigo occidental se haga con su control.

Uno de sus máximos exponentes en la esfera política es el ultranacionalista Vladímir Yirinovsky, líder del Partido Liberal-Demócrata de Rusia (PLDR) ${ }^{44}$. En su discurso de tono populista entremezcla chovinismo con una defensa acerada de las clases más desfavorecidas, lo que le sitúa próximo a los posicionamientos del neosovietismo. Al igual que éste, atribuye a Occidente la responsabilidad de la debacle soviética y aboga por la restauración de las fronteras del antiguo Imperio ruso. Sin embargo, a diferencia de Ziugánov, no descarta la intervención manu militari para alcanzar sus objetivos de política exterior. La lenidad de Moscú en su vecindario estaría precisamente detrás de la conflictividad desatada en la CEI en los albores de los noventa, de la marginación a que se verían sometidas las minorías rusófonas en el extranjero cercano así como del auge del fundamentalismo islámico tras los atentados del 11-S (Jackson, 2003: 27-50).

Finalmente, los estabilizadores o estatistas democráticos (gosudarstvenniki) conjugan el liberalismo democrático occidental con el neonacionalismo autárquico ruso. En su imaginario Rusia constituye una civilización euroasiática que se extiende aproximadamente sobre los límites del Heartland mackinderiano, hecho que no la dota necesariamente de un carácter antioccidental. El modelo de Estado que propugnan se basa en la fortaleza de sus instituciones y la preservación del orden

\footnotetext{
${ }^{44}$ El PLDR es el único partido de extrema derecha con representación en la Duma. En las elecciones legislativas de 2011 obtuvo un 8,14\% de los votos y 56 asientos en la cámara baja rusa. Entre sus principales cometidos destacan la limitación a la libertad religiosa, el restablecimiento de la pena capital, el férreo control de la inmigración, el proteccionismo económico, la nacionalización de los sectores estratégicos de la economía, la provisión gratuita de servicios sociales y la lucha contra la corrupción.
} 
social y político en el interior (Tsygankov y Tsygankov, 2010: 669), así como en un posicionamiento pragmático en política exterior con el que procuran hacer frente a la realidad multipolar de la Posguerra Fría. Aunque admiten que Rusia ya no posee la condición de superpotencia que en su día ostentara la Unión Soviética y no ponen en tela de juicio las nuevas fronteras de la Federación, sí que preconizan la intervención puntual de Moscú en el espacio exsoviético para preservar sus intereses, lo que ha llevado a algunos autores a hablar de una nueva "Doctrina Monroe" 45 . El mantenimiento de la estabilidad interna está íntimamente ligado a su relación con el extranjero cercano, área de gran calado simbólico que alberga a población rusófona y que ostenta además una importancia capital desde el punto de visto de vista político, económico y geoestratégico. En paralelo a la política de vecindad, los arquitectos del estabilizacionismo desean también que su país desempeñe un papel más activo en la economía internacional, y para ello apoyan el desarrollo una política multivectorial que contemplaría incluso la eventual cooperación con organizaciones internacionales tuteladas por Occidente (Smith, 1999: 487-491).

Esta corriente de pensamiento prevaleció durante la mayor parte del mandato de Boris Yeltsin así como en las dos primeras legislaturas de su sucesor en el cargo, Vladímir Putin (Tsygankov, 2003: 117-120). Su vuelta al sillón presidencial el 4 de marzo de 2012 significó, no obstante, un abandono paulatino del pragmatismo anterior en favor de un discurso que propugnaba de manera más nítida la voluntad de Rusia de consolidarse como hegemón en el antiguo espacio soviético. En esta línea, Putin propuso la creación de la Unión Euroasiática, rescatando el proyecto que en 1994 concibiera el presidente kazajo Nursultán Nazarbáyev. Asimismo, recuperó el concepto de "democracia soberana” acuñado en 2006 por Vladislav Surkov, un modelo autoritario promovido también por Nashi ${ }^{46}$ que preconiza la protección de los rusos de los valores importados del extranjero. La progresiva restricción de libertades ha ido de la mano de un acercamiento del Kremlin a la Iglesia Ortodoxa, cuyo simbolismo es explotado como factor agregador supranacional, y que quedó retratado con la condena a prisión en 2012 de tres integrantes de grupo Pussy Riot por su permorfance en la catedral de Cristo Salvador de Moscú. En último término, el Kremlin también ha reforzado la Política de Compatriotas, que inspirada en la denominada "Doctrina Karaganov" ${ }^{47}$ "proclama la defensa de los

\footnotetext{
${ }^{45}$ Por este nombre se conoce al plan introducido en 1823 por el presidente norteamericano James Monroe mediante el que Estados Unidos se arrogaba el derecho exclusivo a intervenir en el continente americano. Para un estudio sobre la utilidad de este concepto en la creación de una unidad política euroasiática, véase Levchuk (2013).

${ }^{46}$ Principal organización política juvenil de apoyo a Putin. Creada en 2005, cuenta actualmente con más de 120.000 miembros.

${ }^{47}$ Nombre bajo el cual se conoce un conjunto de directrices de seguridad concebidas por el académico Serguéi Karaganov en 1992. Éstas hacen énfasis en la necesidad de defender los derechos de las minorías rusófonas en el "extranjero cercano” como medio para garantizar la influencia de Rusia en la región.
} 
derechos de las minorías rusófonas en el extranjero cercano (Pryce, 2013). Una de sus consecuencias más evidentes es el visto bueno de la cámara alta al despliegue de fuerzas militares en Ucrania (RIA Novosti, 1 de marzo de 2014) y la firma de un tratado de integración de la República Autónoma de Crimea en la Federación Rusa (BBC News, 18 de marzo de 2014).

En suma tan sólo los geoeconomicistas y los estabilizadores presentan visiones culturalmente sensibles y políticamente inclusivas. Ambas aceptan las actuales fronteras de la Federación Rusa y proponen maneras innovadoras de recrear el nuevo espacio geográfico. Entre ellas destaca la creación de un sistema colectivo de seguridad en Eurasia que incluyera la participación de todos los actores clave, incluidos China, Irán, las potencias occidentales y Rusia (Tsygankov, 2003: 126).

\section{La teoría del Heartland de Mackinder como piedra angular del pensamiento eurasianista}

La escuela neoeurasianista rusa recurre de manera más o menos explícita a la tesis del Heartland de Halford Mackinder (Clover, 1999: 9) para intentar así enmascarar con un velo de cientificidad sus ambiciones imperiales. Ello pone de manifiesto el renovado interés por la geopolítica y la ubicuidad de su retórica en la Rusia postsoviética. Sin embargo, este hecho no significa que todos sus integrantes se ciñan al pie de la letra a los postulados del geógrafo británico (Wohlforth, 2006: 268), ni tampoco que éstos estén únicamente presentes entre los partidarios de una política exterior expansiva. Tal y como se verá a continuación, sus ecos también retumban en el discurso de quienes abanderan una política exterior de naturaleza pragmática e incluso entre aquellos que abogan por el abandono de cualquier veleidad neoimperial y la apertura a Occidente.

El principal representante del neoeurasianismo civilizacionista, Guennadi Ziugánov, abunda en tres líneas directrices de la obra de Mackinder. En primer lugar, afirma que los contornos del Heartland de 1904 son idénticos desde el punto de vista geográfico a los de Eurasia, entendida ésta como el antiguo espacio soviético, de lo que se deriva la "indiscutida" centralidad de Moscú a lo largo de la historia. En segundo lugar, suscribe la idea que los fundamentos de la identidad geopolítica de Rusia yacen en su carácter eminentemente continental. En último término, adopta la yuxtaposición entre potencias marítimas y continentales del autor británico, que determinaría los verdaderos amigos y enemigos de la Federación independientemente del contexto socioeconómico o el régimen político instalado en el Kremlin. En base a su experiencia, el líder del PCFR proclama que la posición geoestratégica de Rusia seguirá alimentando inexorablemente la rusofobia de Occidente y la enemistad inveterada que se profesan mutuamente desde tiempos inmemoriales. Asimismo, prescribe un "imperialismo aislacionista" de carácter autárqui- 
co que otorgaría preeminencia a la relaciones con el extranjero cercano (Bassin y Aksenov, 2006: 102-105).

La valoración de Aleksandr Duguin, uno de los principales ideólogos del expansionismo neoeurasianista, coincide con la de Ziugánov en una serie de puntos. El académico moscovita también identifica el Heartland o "Área pivote" (osevoi areal) con los contornos del Estado ruso, avala la oposición marítimo-continental de Mackinder y comulga con el determinismo geográfico del geógrafo británico. Sin embargo, a diferencia del líder comunista, concibe Eurasia como la unión de dos entidades geográficas, Europa y Asia, igualando así el espacio euroasiático a la noción mackinderiana de "Isla-mundial". La posición de centralidad de Rusia la facultaría para ejercer de centro neurálgico del continente, requisito sine qua non para satisfacer el imperativo último de integrar la región en una única unidad administrativa. Conviene apuntar, empero, que Mackinder no considera al Heartland inherentemente expansionista, de ahí que el recurso a las ideas del geógrafo británico pueda ser interpretado como una simple licencia tomada por Duguin para justificar su vocación imperialista (Bassin y Aksenov, 2006: 102-105).

A diferencia de estos autores, otros próceres del pensamiento geopolítico ruso impugnan las tesis de Mackinder esgrimiendo razones muy diversas. Uno de los abanderados del estatismo democrático, Kamaludín Gadyiyev, arremete contra su determinismo geográfico por tres frentes. Por un lado, el examen de la historia saca a flote algunas de las limitaciones de la teoría del Heartland, como el hecho que esta última relegue a los nodos contemporáneos de América del Norte y la región de Asia-Pacífico a la condición de periferia. Por otro, el desarrollo tecnológico permitiría salvar cualquier barrera fisiográfica en la actualidad, reduciendo y comprimiendo el espacio-tiempo a niveles insospechados un siglo atrás. En última instancia, la integración en la economía global y la adopción de la democracia liberal desdibujaría el carácter autárquico de la civilización que ocuparía el Área Pivote. Vadim Tsymburski, por su parte, hace lo propio al considerar que el Heartland, tal y como los demarcara el geógrafo británico en sendas obras de 1904 y 191948, no se corresponde con el espacio histórico-geográfico genuino de la nación rusa (Bassin y Aksenov, 2006: 102-105). Finalmente, Dmitri Trenin (2002: 309-325), adalid del internacionalismo institucional, rechaza de plano la vigencia de la geopolítica clásica, y defiende que el período de Rusia como Heartland de Eurasia ha expirado. El director del Carnegie Moscow Center aboga por una retirada del espacio soviético a tenor de la incapacidad demostrada para contrarrestar la penetración de Occidente, y únicamente contempla la posibilidad de emprender acciones ad hoc en determinados puntos calientes de la región siempre y cuando Estados Unidos muestre su respaldo.

${ }^{48}$ Véase Mackinder (1904). 
A lo largo de la historia, la política de Rusia hacia este territorio se ha caracterizado por una dualidad que conjuga el reconocimiento desde tiempos de los zares del hecho diferencial étnico, con su significación en la conformación de la identidad nacional rusa (Sengupta, 2009: xxiii). Desde el siglo XIX las principales corrientes nacionalistas de Moscú han estado más preocupadas por el flanco occidental del país, considerando su frontera sur como un área económica y culturalmente retrasada que constituía una carga adicional para Moscú. De hecho, el eurasianismo clásico presentaba a Rusia como la heredera del Imperio mongol y relegaba al ostracismo cualquier hipotética filiación que pudiera comprometer sus premisas ${ }^{49}$. A pesar del menosprecio oficialista secular hacia los pueblos allende sus fronteras, la legitimidad del proyecto político ruso sigue recayendo sobre la capacidad de mantener al espacio euroasiático bajo su influencia, siendo esta demarcación imprescindible a la hora de evocar la gloria de épocas pasadas e irreemplazable en el imaginario irredentista de buena parte de la población (Laruelle, 2008b: 29-35).

\subsection{La crisis de Ucrania de 2013 y 2014. La pugna por el control de una pieza clave en el tablero geopolítico euroasiático}

La importancia que otorga Moscú a su frontera occidental ha quedado retratada en la gestión del episodio de conflictividad que viene azotando la República de Ucrania desde que en noviembre de 2013 se iniciaran las protestas del Euromaidán en la plaza de la Independencia de Kiev. Conviene tener presente de entrada que en el imaginario nacionalista ruso Ucrania constituye el corazón cultural y ancestral de la cultura eslava, habida cuenta de que el grupo étnico que fundó el Ducado de Moscú y posteriormente el Imperio ruso remonta sus orígenes como comunidad política al gran Estado ruso de Kiev. Dejando a un lado la variable identitaria, el valor geoestratégico del territorio ucraniano fue puesto de relieve ya en 1919 por Halford Mackinder (1919: 194) al incluirlo en las estribaciones occidentales de su Heartland. Tras la desintegración soviética el politólogo norteamericano Zbigniew Brzezinski (1997: 41) lo incorporó a su nómina de pivotes geopolíticos, esto es, a aquellos "Estados cuya importancia se deriva no sólo de su poder y motivación sino más bien de su localización sensible y de las consecuencias de su condición potencialmente vulnerable para el comportamiento de actores geoestratégicos". Andrew Wilson (2000: 292), por su parte, certificaría la preeminencia de Ucrania en el tablero geopolítico euroasiático al apuntar que es "importante precisamente porque

\footnotetext{
${ }^{49}$ Uno de los casos más ilustrativos fue el de la dinastía timurid, con la que se negaba cualquier vinculación. De linaje turco-mongol, reinó sobre el actual Irán, Afganistán y parte de Asia Central así como en áreas de Pakistán, India, Mesopotamia, Anatolia y el Cáucaso entre los siglos XIV y XVI.
} 
podía escoger su camino. Su elección entre la integración con Europea o el retorno a la esfera rusa tendrá un efecto vital en el equilibrio de poder en el conjunto de la región euroasiática”.

Realizadas estas precisiones, la actitud del Kremlin en la crisis ucraniana puede interpretarse desde dos aproximaciones teóricas contrapuestas. La primera de ellas postula un escenario siniestro en el que los dignatarios moscovitas abrazarían las tesis del eurasianismo más agresivo para desplazar las fronteras de la Federación hacia el oeste. El casus belli que supuestamente justificaría la acción sería la entrada en el gobierno interino ucraniano de facciones de extrema derecha que abogarían por la supresión de los derechos lingüísticos de la minoría rusófona en el país ${ }^{50}$. Sin embargo, a diferencia de otros casos como la agresión georgiana a Osetia del Sur en 2008, el Estado ucraniano no emprendió acciones que atentaran contra la integridad física de la población civil en Crimea u otras regiones de mayoría rusófona. Asimismo, el voto de estos territorios había resultado clave para que el prorruso Víktor Yanukóvich se hiciera con la victoria en las elecciones presidenciales de 2010. Con una comunidad rusófona que ronda el 30\% de la población del país, Moscú tenía asegurada la cooperación de Kiev en materia económica y de seguridad, por lo que ganar Crimea para perder Ucrania no parecería de acuerdo a esta lógica una decisión en absoluto racional (Charap y Darden, 2014: 10).

La segunda aproximación concibe el movimiento de Rusia como un esfuerzo reactivo para evitar lo que los dignatarios del Kremlin percibían como una amenaza directa a los intereses nacionales de la Federación (Charap y Darden, 2014: 11). Para entender esta postura resulta indispensable analizar las causas últimas del conflicto, que exigen retrotraernos a mucho antes de los hechos de noviembre de 2013 así como centrar el foco de atención en las relaciones entre Rusia y Estados Unidos. Los eventos que precipitaron la invasión de Crimea el 28 de febrero son, pues, anteriores a las protestas del Euromaidán, al debate entre la aproximación a la Unión Europea o la participación en la Unión Económica Euroasiática, e incluso al cisma insalvable entre Yulia Timoshenko y Víktor Yanúkovich. Se remontan a principios de los noventa, cuando el presidente George H. W. Bush y el Secretario de Estado James Baker prometieron a Mijaíl Gorbachov que la OTAN no se ampliaría hacia el este (Kotkin, 2014).

Los defensores de la aproximación de Kiev a las estructuras occidentales, como el diplomático norteamericano George Kennan y sectores liberales de la clase política moscovita, advirtieron en su momento que un comportamiento antirruso generaría hostilidad en Moscú y acabaría siendo del todo contraproducente para los

\footnotetext{
${ }^{50}$ Conviene tener presente que si bien en un principio la Rada Suprema votó la abolición de la Ley sobre los Principios de la Política Lingüística Estatal de 2012, que oficializaba el uso en la Administración de otras lenguas distintas al ucraniano en aquellas regiones en las que fueran habladas por un mínimo del 10\% de la población, finalmente el presidente de turno Oleksandr Turchinov se negó a su ratificación.
} 
intereses de estabilidad compartidos. Sin embargo, las sucesivas administraciones norteamericanas hicieron caso omiso a esta premisa y optaron por desplegar una política de faits accomplis destinada a ganar terreno de manera progresiva en la esfera de influencia clásica de Rusia. Así las cosas, patrocinaron la expansión hacia el este de la Unión Europea y la OTAN ${ }^{51}$, dieron su visto bueno al despliegue de tropas occidentales en antiguas repúblicas soviéticas, emprendieron controvertidas campañas militares sobre aliados tradicionales rusos como Serbia, Irak y Libia, apoyaron las denominadas "revoluciones de colores", se mostraron impasibles ante la marginalización de las minorías rusófonas en los países bálticos, bendijeron la declaración unilateral de independencia de Kósovo al tiempo que deploraban el reconocimiento ruso de Abjasia y Osetia del Sur, y no condenaron en un principio la participación de grupos filonazis en el derrocamiento del gobierno legítimo ucraniano en febrero de 2014 (Lukin, 2014: 85-91).

La actitud occidental acabaría empoderando a aquellos que en Moscú mostraban su rechazo abierto a la asimilación occidental y propugnaban en su lugar la recuperación de la condición de gran potencia en un mundo multipolar. Por consiguiente, pese que una visión apriorística podría arrastrarnos a pensar que Rusia pretende recuperar el espacio cedido en una nueva guerra ideológica de suma cero en la que Ucrania sería una pieza más del dominó que seguiría a Georgia, la evaluación en perspectiva de los hechos revela que Moscú no ha implementado una política expansionista arbitraria, sino antes bien un "expansionismo defensivo" (Kotkin, 2014) acentuado por un sentimiento de inferioridad e "inseguridad geográfica" (Kaplan, 2014) enraizado en lo más profundo de la psique rusa. Ucrania constituye, por tanto, una última línea roja para la administración Putin debido a su valor sentimental en la línea de fractura entre la civilización occidental y la ortodoxa (Huntington, 1993), y a su emplazamiento privilegiado como "cabeza de puente" (Brzezinski, 1997: 57) en el margen europeo del Heartland.

\section{Consideraciones finales: la restitución de la centralidad del nacionalismo ruso de corte eurasianista}

El nacionalismo ha adquirido una posición preponderante en el pensamiento geopolítico ruso de Posguerra Fría. Desde su nacimiento a mediados del siglo XIX, el ideario nacionalista ha permeado paulatinamente en todas las capas de la sociedad hasta alcanzar una presencia prácticamente omnímoda en el discurso postsoviético oficial. Su progresión desde la más absoluta irrelevancia dista mucho, no obstante,

\footnotetext{
${ }^{51}$ En la cumbre de Bucarest de 2008 los miembros de la OTAN acordaron que Ucrania formaría parte de la Alianza Atlántica “algún día”.
} 
de ser lineal, y en el largo peregrinaje hasta hacerse con la hegemonía ha tenido que enfrentarse a coyunturas adversas en las que se ha visto desplazado de la posición de centralidad, siendo postergado e incluso proscrito - al menos a título nominalpor las autoridades. A pesar de ello, la gran plasticidad de su mensaje unido al potente componente emocional que alberga lo dotan de una gran resiliencia que le ha permitido salir a flote en los momentos más difíciles y coronarse bajo semblantes muy diversos como piedra angular de la doctrina profesada por las principales escuelas geopolíticas actuales. La más exitosa de las múltiples formas en las se manifiesta es la corriente neoeurasianista, que pese a carecer de un programa unitario condensa las viejas aspiraciones imperiales del pueblo ruso sobre el continente euroasiático, un territorio etéreo cuya área central es homologable al Heartland de Mackinder. Codiciada también por los adversarios tradicionales de Moscú, algunos autores no han dudado en designar la pugna por su control como el nuevo "Gran Juego" 52 . Independientemente de si el escenario actual merezca dicha consideración o no, la conflictividad en Ucrania pone una vez más de relieve la trascendencia de la región en el imaginario nacionalista ruso y su rehabilitación como pieza central del tablero geopolítico euroasiático.

\section{Bibliografía}

Anderson, T. (1967) Russian Political Thought: An Introduction. Ithaca: Cornell University Press.

Astrov, A., y Morozova, N. (2008) "The Silence of the Law or Geopolitics from the Heartland". Ponencia presentada en ISA's 49th Annual Convention: "Bridging multiple divides", San Francisco.

Bassin, M. (2001) Classical Eurasianism and the Geopolitics of Russian Identity. Texto no publicado, University College London.

Bassin, M. (2008) "Eurasianism «Classical» and «Neo»: The Lines of Continuity", en T. Mochizuki (ed.) Beyond the Empire: Images of Russia in the Eurasian Cultural Context. Sapporo: Slavic Research Centre, 297-294.

Bassin, M., y Aksenov, K. E. (2006) "Mackinder and the Heartland Theory in PostSoviet Geopolitical Discourse”. Geopolitics, vol. 11, núm. 1, 99-118.

BBC News, "Ukraine Crisis: Putin Signs Russia-Crimea Treaty". [URL: $<$ http://www.bbc.com/news/world-europe-26630062>. Consultado el 18 de marzo de 2014].

\footnotetext{
${ }^{52}$ El término "Gran Juego", acuñado por Arthur Conolly, se refiere originariamente a la lucha entre los imperios británico y ruso por la hegemonía en Asia Central entre aproximadamente el Tratado de Gulistán de 1813 y la Entente anglo-rusa de 1907.
} 
Berdiáyev, N. (1947) The Russian Idea. Londres: G. Bles.

Billington, J. H. (2004) Russia in Search of Itself. Washington, D.C: Johns Hopkins University Press.

Biryukov, S. (2013) "Eurasian Doctrine of Kazakh President Nursultan Nazarbayev. «Thinking Space»”. Journal of Eurasian Affairs, vol. 1, núm. 1, 15-18.

Brubaker, R. (1996) Nationalism Reframed: Nationhood and the National Question in the New Europe. Cambridge: Cambridge University Press.

Brudny, Y. M. (2000) Reinventing Russia: Russian nationalism and the Soviet state, 1953-1991. Cambridge: Harvard University Press.

Brzezinski, Z. (1997) The Grand Chessboard. American Primacy and Its Geostrategic Imperatives. Nueva York: Basic Books.

Carrère d'Encausse, H. (1984) L'empire éclaté: la révolte des nations en U.R.S.S. París: Flammarion.

Carter, S. K. (1990) Russian Nationalism: Yesterday, Today, Tomorrow. Nueva York: St. Martin's Press.

Castells, M. (2003) La era de la informacion. Vol. 2: El poder de la identidad. Madrid: Alianza.

Charap, S., y Darden, K. (2014) "Russia and Ukraine”. Survival: Global Politics and Strategy, vol. 56, núm. 2, 7-14.

Charillon, F. (2004) "EU's interventionism in its "near abroad”, en W. Carlsnaes, H. Sjursen y B. White (eds.) Contemporary European Foreign Policy. Londres: Sage, 252-264.

Clover, C. (1999) "Dreams of the Eurasian Heartland". Foreign Affairs, vol. 78, núm. 2, 9-13.

Clunan, A. L. (2009) The Social Construction of Russia's Resurgence: Aspirations, Identity, and Security Interests. Baltimore: The Johns Hopkins University Press.

Cucó, A. (1999) El despertar de las naciones: la ruptura de la Unión Soviética y la cuestión nacional. Valencia: Servei de Publicacions de la Universitat de València.

Dawisha, K., y Parrott, B. (1994) Russia and the New States of Eurasia: The Politics of Upheaval. Cambridge: Cambridge University Press.

Dugin, A. (2014) "La dinámica ideológica en Rusia y los cambios del curso de su política exterior" [URL: <http://www.4pt.su/es/content/la-dinamica-ideologicaen-rusia-y-los-cambios-del-curso-de-su-politica-exterior>. Consultado el 11 de febrero de 2014].

European Comission Against Racism and Intolerance (2013) ECRI Report on the Russian Federation. Consejo de Europa.

Fragner, B. G. (2001) "«Soviet Nationalism»: An Ideological Legacy to the Independent Republics of Central Asia”, en W. Van Schendel y E. J. Zürcher (eds.) Identity Politics in Central Asia and the Muslim World: Nationalism, Ethnicity and Labour in the Twentieth Century. Nueva York: I.B. Tauris, 13-33.

Gellner, E. (1983) Nations and Nationalism. Ithaca: Cornell University Press. 
Gorbachov, M. S. (1988) Perestroika: New Thinking for Our Country and the World. Nueva York: Harper \& Row.

Hauner, M. (1992) What is Asia to Us?: Russia's Asian Heartland Yesterday and Today. Londres: Routledge.

Huntington, S. P. (1998) The Clash of Civilizations and the Remaking of World Order. Londres: Touchstone.

Huttenbach, H. R. (1990) "Introduction: Towards a Unitary Soviet State: Managing a multinational society, 1917-1985”, en H. R. Huttenbach (ed.) Soviet Nationality Policies: Ruling Ethnic Groups in the USSR. Londres: Mansell, 1-8.

Jackson, N. J. (2003) Russian Foreign Policy and the CIS: Theories, Debates and Actions. Londres: Routledge.

Jahn, H. F. (2004) “«Us»: Russians on Russianness”, en S. Franklin y E. Widdis (eds.) National Identity in Russian Culture: An Introduction. Nueva York: Cambridge University Press, 53-73.

Kaiser, R. J. (1997) "Nationalism and Identity”, en M. J. Bradshaw (ed.) Geography and Transition in the Post-Soviet Republics. Chichester: Wiley, 9-30.

Kaplan, D., y Herb, G. (1999) Nested Identities: Nationalism, Territory and Scale. Lanham: Rowman \& Littlefield Publishers.

Kaplan, D., y Herb, G. (2011) "How Geography Shapes National Identities". National Identities, vol. 13, núm. 4, 349-360.

Kaplan, R. D. (2012) The Revenge of Geography: What the Map Tells Us about Coming Conflicts and the Battle Against Fate. Nueva York: Random House.

Kaplan, R. D. (2014) “Crimea: The Revenge of Geography?”. Forbes [Puesto en línea el 14 de marzo de $2014 . \quad$ URL: $<$ http://www.forbes.com/sites/stratfor/2014/03/14/crimea-the-revenge-ofgeography/>. Consultado el 23 de octubre de 2014].

Kennedy, P. M. (2004) Auge y caída de las grandes potencias. Barcelona: Debolsillo.

Kotkin, J. (2014) “Crimea: Russia is Harvesting the Seeds Sown in the 1990s”. The Barefoot Strategist [Puesto en línea el 2 de marzo de 2014. URL: $<$ https://medium.com/the-bridge/crimea-russia-is-harvesting-the-seeds-sown-inthe-1990s-54892d22ccbb>. Consultado el 24 de octubre de 2014].

Lake, D. A., y Morgan, P. M. (1997) Regional Orders: Building Security in a New World. University Park: Pennsylvania State University Press.

Laruelle, M. (2008a) Russian Eurasianism: An Ideology of Empire. Washington: Johns Hopkins University Press.

Laruelle, M. (2008b) "Russia's Central Asia Policy and the Role of Russian Nationalism”. Silk Road Paper, abril.

Laruelle, M. (2009) In the Name of the Nation: Nationalism and Politics in Contemporary Russia. Nueva York: Palgrave Macmillan.

Levada Analytical Center (2013) Russian public opinion 2012-2013. Moscú. 
Levchuk, K. (2013) Eurasiansim: A Russian Monroe Doctrine? Budapest: Central European University.

Light, M. (2003) "In Search of an Identity: Russian Foreign Policy and the End of Ideology". Journal of Communist Studies and Transition Politics, vol. 19, núm. 3, 42-59.

Lukin, A. (2014) "What the Kremlin Is Thinking”. Foreign Affairs, vol. 93, núm. 4, 85-93.

Mackinder, H. J. (1904) “The Geographical Pivot of History”. The Geographical Journal, vol. 23, núm. 4, 421-437.

Mackinder, H. J. (1919) Democratic Ideals and Reality: A Study in the Politics of Reconstruction. Londres: Constable and Company.

Mackinder, H. J. (1943) "The Round World and the Winning of the Peace”. Foreign Affairs, vol. 21, núm. 4, 595-605.

Millar, J. R. (2004) Encyclopedia of Russian History. Nueva York: Macmillan Reference USA.

Ministry of Foreign Affairs of the Russian Federation (2000) "National Security Concept of the Russian Federation”. [URL: <http://www.mid.ru/bdomp/nsosndoc.nsf/1e5f0de28fe77fdcc32575d900298676/36aba64ac09f737fc32575d9002 bbf31!OpenDocument>. Consultado el 10 de febrero de 2014].

Nogué, J. (1998) Nacionalismo y territorio. Lleida: Editorial Milenio.

Ó Tuathail, G. (1996) Critical Geopolitics. The Politics of Writing Global Space. Londres: Routledge.

Pearson, R. (1991) "The Historical Background to Soviet Federalism”, en A. Macauley (ed.) Soviet Federalism, Nationalism and Economic Decentralisation. Leicester: Leicester University Press, 13-32.

Pohl, J. O. (1999) Ethnic Cleansing in the USSR: 1937-1949. Westport: Greenwood Press.

Pryce, P. (2013) "Putin's Third Term: The Triumph of Eurasianism?”. Romanian Journal of European Affairs, vol. 1, núm. 3, 25-43.

RIA Novosti (2014) "Russian Parliament Approves Military Action in Ukraine" [URL: <http://en.ria.ru/russia/20140301/188000380/Parliament-Approves-PutinRequest-for-Military-Action-in-Ukraine.html>. Consultado el 1 de marzo de 2014].

Savarino, F. (2007) "Historia e identidad nacional: La perspectiva etnosimbólica". Navegando, vol. 1, 39-44.

Sengupta, A. (2009) Heartlands of Eurasia. Lanham: Lexington Books.

Sheey, A. (1991) "Ethnographic Developments and the Soviet Federal System", en A. Macauley (ed.) Soviet Federalism, Nationalism and Economic Decentralisation. Leicester: Leicester University Press, 56-88.

Shlapentokh, D. (1997) "Eurasianism. Past and Present”. Commmunist and PostCommunist Studies, vol. 30, núm. 2, 129-151. 
Sloan, G. (1999) "Sir Halford J. Mackinder: The Heartland Theory Then and Now". Journal of Strategic Studies, vol. 22, núm. 2, 15-38.

Smith, A. (1983) Theories of Nationalism. Trumbull: Holmes \& Meier.

Smith, A. (1991) National Identity. Reno: University of Nevada Press.

Smith, G. (1999) "The Masks of Proteus: Russia, Geopolitical Shift and the New Eurasianism”. Transactions of the Institute of British Geographers, vol. 24, núm. 4, 481-494.

SOVA. Center for Information and Analysis (2014) "Racism and Xenophobia:

Preliminary Summary for 2013”. [URL: <http://www.sovacenter.ru/en/xenophobia/news-releases/2014/01/d28754>. Consultado el 10 de febrero de 2014].

Suny, R. G. (1993) The Revenge of the Past: Nationalism, Revolution, and the Collapse of the Soviet Union. Stanford: Stanford University Press.

Taibo, C. (1996) Los jerarcas soviéticos: de Lenin a Gorbachov. Madrid: ArcoLibros.

Taibo, C. (1999) La Unión Soviética: el espacio ruso-soviético en el siglo XX. Madrid: Síntesis.

Taibo, C. (2000) La explosión soviética. Madrid: Espasa Calpe.

Tishkov, V. A. (1997) Ethnicity, Nationalism and Conflict in and after the Soviet Union: The Mind Aflame. Londres: Sage.

Tolz, V. (2010) “The West”, en W. J. Leatherbarrow y D. Offord (eds.) A History of Russian Thought. Cambridge: Cambridge University Press, 197-216.

Trenin, D. (2002) The End of Eurasia Russia on the Border Between Geopolitics and Globalization. Moscú: Carnegie Endowment for International Peace.

Tsygankov, A. P. (1997) "From International Institutionalism to Revolutionary Expansionism: The Foreign Policy Discourse of Contemporary Russia”. The International Studies Review, vol. 41, núm. 2, 247-268.

Tsygankov, A. P. (2003) “Mastering Space in Eurasia: Russia’s Geopolitical Thinking after the Soviet Break-up”. Communist and Post-Communist Studies, vol. 36, núm. 1, 101-127.

Tsygankov, A. P., y Tsygankov, P. A. (2010) "National Ideology and IR Theory: Three Incarnations of the "Russian Idea»". European Journal of International Relations, vol. 16, núm. 4, 663-686.

Utechin, S. (1964) Russian Political Thought: A Concise History. Nueva York: Praeger.

Velliste, T. (1993) Discurso de Trivimi Velliste en la conferencia NUPI-CSIS sobre seguridad báltica y nórdica. [URL: <http://www.vm.ee/?q=en/node/3596>. Consultado el 12 de marzo de 2014].

Weber, M. (1920) Gesammelte Aufsätze zur Religionssoziologie. Mohr: Tübingen.

Wight, M. (1992) International Theory: The Three Traditions. Nueva York: Holmes \& Meier Publishers. 
Wilson, A. (2000) The Ukrainians: Unexpected Nation. New Haven y Londres: Yale University Press.

Wohlforth, W. C. (2006) "Heartland Dreams: Russian Geopolitics and Foreign Policy”, en W. Danspeckgruber (ed.) Perspectives on the Russian State in Transition. Princeton: The Liechtenstein Institute on Self-Determination at Princeton University, 265-287.

Zapater Espí, L. (2005) El nacionalismo ruso: la respuesta euroasiática a la globalización. Valencia: Universitat Politècnica de València.

Ziugánov, G. (1997) My Russia: The Political Autobiography of Gennady Zyuganov. Armonk: Sharpe. 